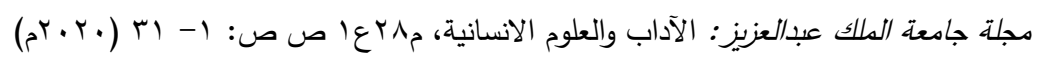

DOI:10.4197/Art.28-1.1

\title{
استشراف المستقبل والتخطيط له وحاجة الدعوة والداعية إليه دراسة تأصيلية في بيان أهميته ووسائل معرفته من خلال النصوص الثرعية
}

\author{
د. علي بن محمد عبدالله الشنقيطي \\ أستاذ الدعوة والدراسات الإسالامية \\ كلية الآداب والعلوم الإنسانية - جامعتة طيبة، المدينتة المنورة
}

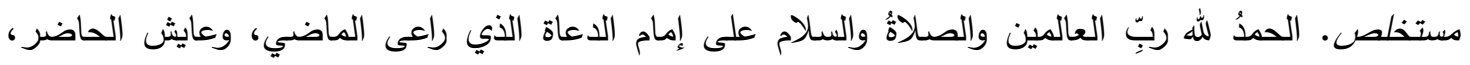
واستشرف المستقبل وخطط له، ووجه الدعوة والدعاة إلى ما سيقدمون عليه في قابل الأيام ورضي الله عن صحابته الكرام الذين قاموا بواجب الدعوة إلى الله وفَقِهوها ووضعوا كل شيء في مرتبته بالعدل، فبلّغوا الرسالةً وأدوا الأمانة، وقالوا للناس حسنا فإنّ من البصيرة في الدعوة إلى الله التي هي وظيفة الأنبياء، ورسالة الله في كتابه الحكيم؛ أن تقوم على خطط محكمة تهاي للتي هي أقوم، ولذلك كان استشراف المستقبل والتخطيط له أولى من آن آله مفاجآته دون سابق توقع وتقدير، فنجاح الداعية في الغالب متوقف على قوة أو ضعف استشرافه للمستقبل،

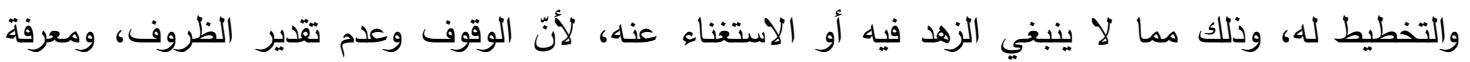
الخطوات القادمة، أمر غير مقبول ولا تحصل منه نتيجة، وهو فشل وتخبط والأجدر بأهل الحقّ أن يأخذوا بالأسباب، فيخططوا ويتوكلوا على الله، ويغرقوا بين الأمنيات والإمكانات، ولا ينطلقون من خيال، إنما من واقع وهول مدروس • وموضوع المستقبل واستشرافه؛ يشترك فيه جميع البشر ، فالحياة التي يعيشونها تبحر بهم إلى المستقبل،

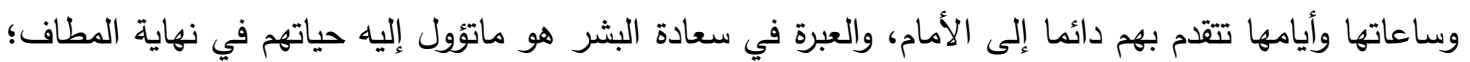
لأنّ العبرة بالخواتيم، وغيابه في حياة الناس عموما والدعاة على الأخص يؤدي إلى كثير من التخبط والعشوائية في المواقف وتقدير الخطوات، بل قد يجعل الواحد يعيش في دوامة وحيرة لعدم وضوح الرؤية عنده، وللغموض الذي يسيطر على مستقبله وطموحاته، وهناك تصورات خاطئة لبعض المفاهيم الشرعية تزهّد البعض في الانطلاق والتخطيط والتفكير في المستقبل، فيعيش حياته خاملا، لا يفكر في أبعد من قدميه .واستشراف المستقبل

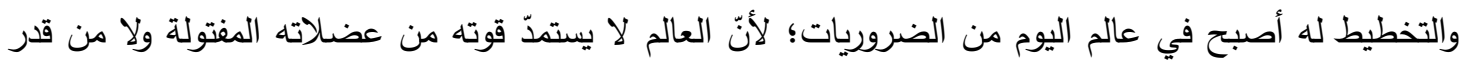
الحديد الذي يملكه؛ لكنّه يستمدّ قوّته بالدّرجة الأولى من قوّة استشرافه للمستقبل والتخطيط له، وبعد النظر، مله 
واستحضار النظرة المستقبلية للأمور، وهذه المعاني والمعالم لا يمكن أن تستغني عنها الدعوة إلى الله في عصر

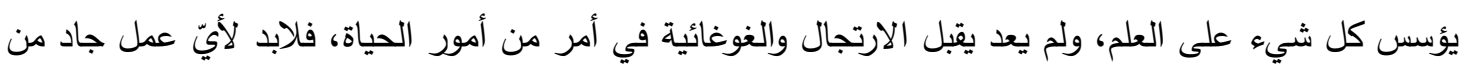
الدراسة قبل العزم عليه، ولابد من الإقناع بجدواه قبل البدء فيه ولابد من التخطيط قبل التنفيذ، ولذلك فيعتبر استشراف المستقبل والتخطيط له والفقه فيه معلما مهما في نجاح الدعوة والداعية؛ لأنّه وجد من الدعاة المخلصين من تأثر بواقع المسلمين المرير، وماهم فيه من ضعف، فتحمس للتغيير، وإنقاذهم مما هم فيه، وانطلق في تنفيذ واجب الدعوة إلى الله ؛ دون استشراف مستقبل أيامه ودون أن يخطط ويدرس حجم الواجب الذي عليه أن يؤديه،

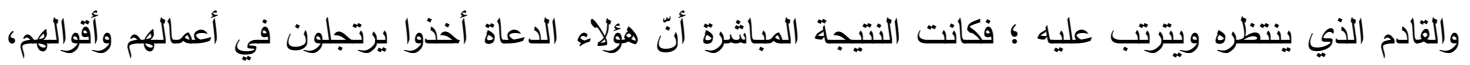
ويتخبطون في منهجياتهم وأساليبهم ووسائلهم، منطلقين في ذلك من الرغبة في تحقيق واجباتهر، غاضّين النظر عن إمكاناتهم وقدراتهم. وتتأكد الحاجة للنظر إلى المستقبل واستشرافه والتخطيط له في حياة الدعوة والداعية ،لأنّ العمل الدعويّ بحاجة ماسة إلى رؤية مستقبلية متكاملة وواضحة، بعيدا عن الارتجال والعشوائية والتخبط، وردّات الأفعال، والتي نلحظها

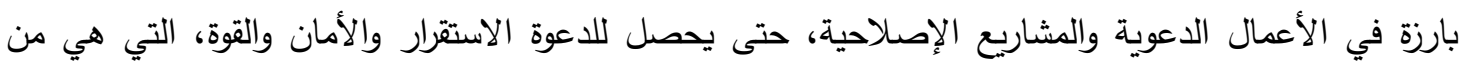
صميم الإعداد المأمور به شرعاً فلنعدّ في هذا المجال مانستطيع من قوة الإحيه.

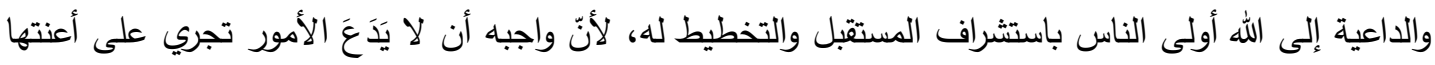

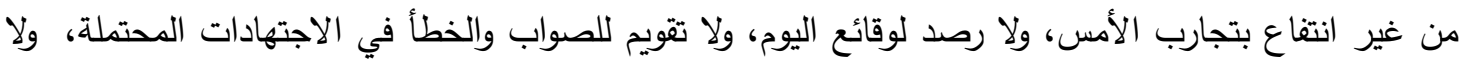

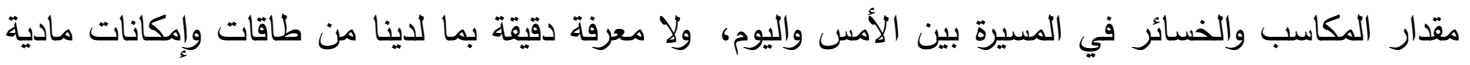
ومعنوية، ظاهرة أو كامنة، مستغلة أو مهدرة، وما هي مصادر القوة ونقاط الضعف ولفئ ، التي ينبغي أن يقدرها، ويتحسب لها قبل وقوعها، ونحو ذلك من النظر والتأمل. ولا ينبغي أن يُفهم أنّ استشراف المستقبل والتطلع لمعرفته أمر شكلي، بل هو عين الفقه والبصيرة في الدين؛ للإحسان في الدعوة والتخطيط لها الذي هو مهمة الدعاة إلى الله والباحثين ، فلا ينبغي أن تقتصر دراساتهم على النى

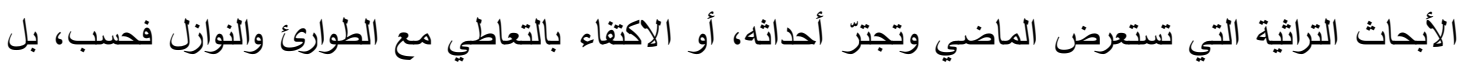

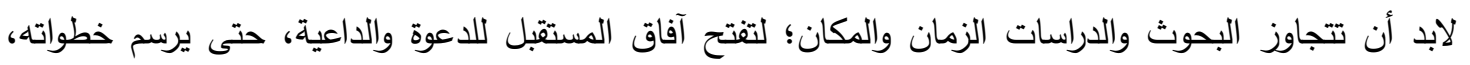

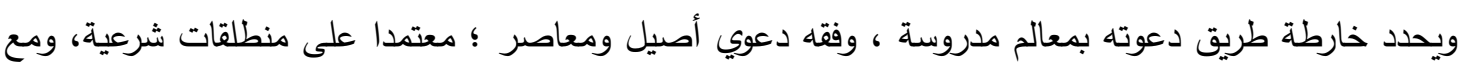
التقدير والاحترام لكل الماضي والحاضر لكن الاهتمام بالمستقبل لابدّ أن يكون حاضرا دائما في ذهن الداعية، وظاهرا في جهوده العلمية والعملية؛ لأنه نتيجة منطقية للماضي والحاضر • وسنحرص في هذه الورقات على تأصيل هذه الحقيقة، وفقه شيء من معالمها، والوقوف على أبرز الوسائل في معرفة المستقبل، بعد التمهيد لهذه الوسائل والطرق بفصل يحسن فيه التعريج على أهمية استشراف المستقبل في حياة الدعوة والداعية، وإلا فإنّ موضوع استشراف المستقبل والتخطيط له؛ موضوع واسع وعلاقته بالدعوة والداعية

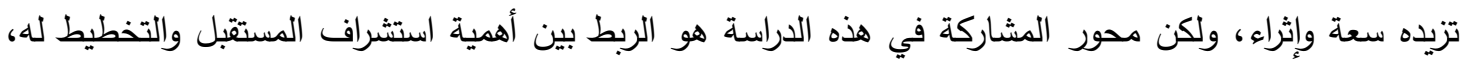
وبيان حاجة الدعوة والداعية إليه في العصر الحديث الذي أصبحت كل المشاريع فيه لا تقوم إلا على الدراسات

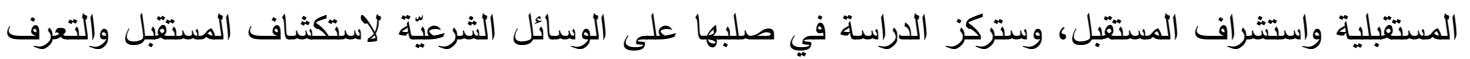


عليه وتجليته، كل ذلك بالتأمل في النصوص، من خلال الأحاديث الشريفة والهدي النبوي لإمام الدعاة لتكون هذه ( استشراف المستقبل والتخطيط له وحاجة الاعوة

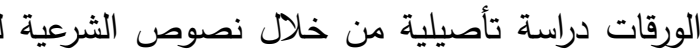
والداعية إليه ) .

على الله، ويفرقوا بين الأمنيات والإمكانات، ولا

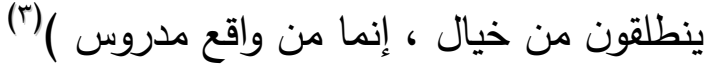

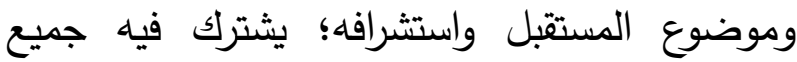
البشر، فالحياة التي يعيشونها تبحر بهم إلى والى المستقبل، وساعاتها وأيامها تتقدم بهم دائما إلى لى إلى الأمام، والعبرة في سعادة البشر هو ماتؤول إليه

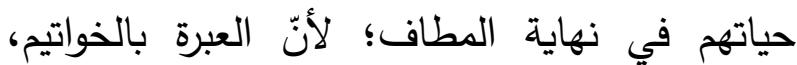

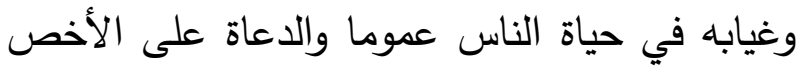
يؤدي إلى كثير من التخبط والعشوائية في المواقف وتقدير الخطوات، بل قد يجعل الواحد يعيش في

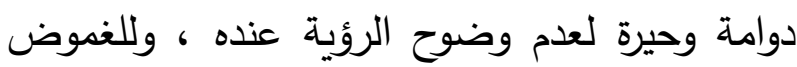

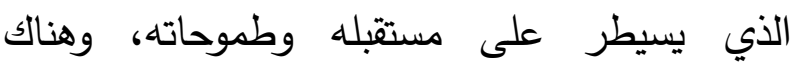
تصورات خاطئة لبعض المفاهيم الثرعية تزهّد

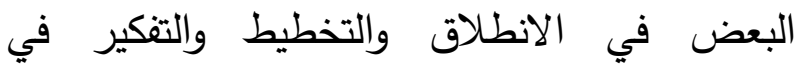
المستقبل، فيعيش حياته خاملا ، لا يفكر في أبعد

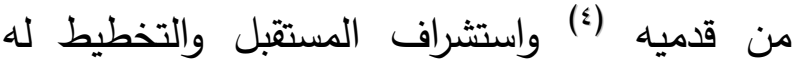

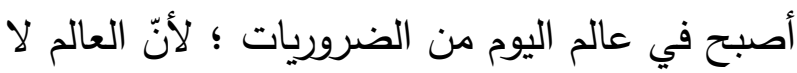
يستمدّ قوته من عضلاته المفتولة ولا من قدر الحديد الذي يملكه ؛ لكنّه يستمدّ قوّته بالدّرجة الأولى من لالّن قوّة استشرافه للمستقبل والتخطيط له وبعد النظر فيه،

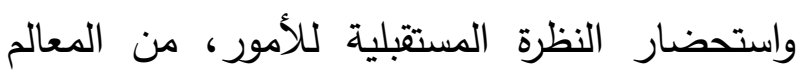

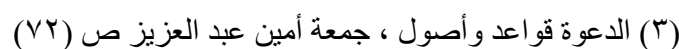

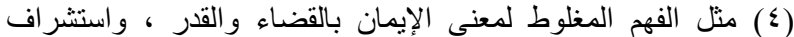

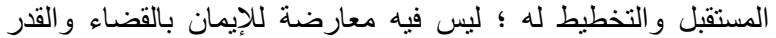

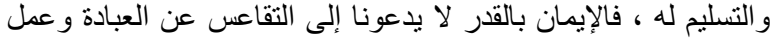
الخير ، فنحن:( نفر من قدر الله إلى قدر الله ) ماللك في الموطا (190/1 19

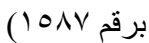

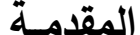

الحمدُ لله ربّ العالمين، القائلِ على لسان رسوله

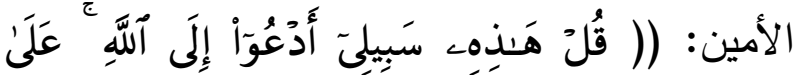

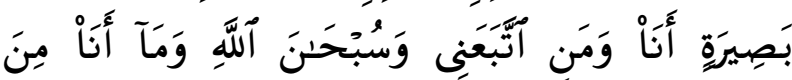

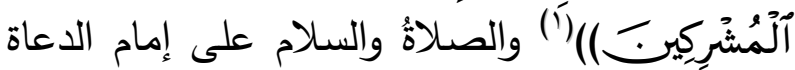
 المستقبل وخطط له ، ووجه الدعوة والدعاة إلى ما

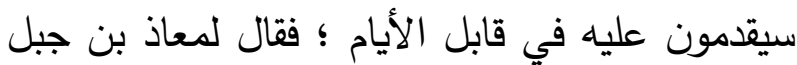

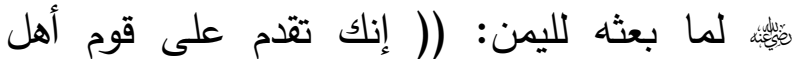

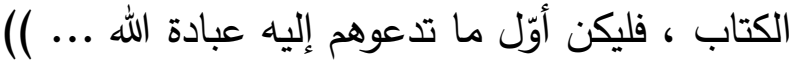

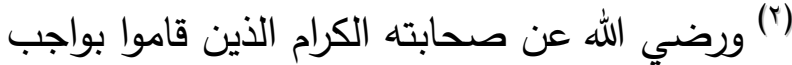

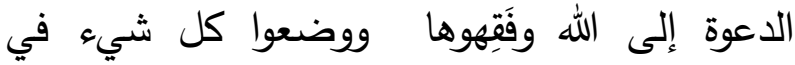
مرتبته بالعدل، فبلّغوا الرسالةً وأدوا الأمانة ، وقالوا للناس حسنا وبعد فإنّ من البصيرة في الدعوة إلى الله ؛ أن تقوم على

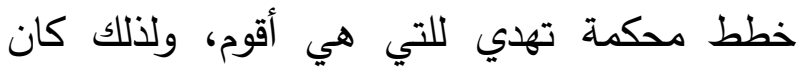
استشراف المستقبل والتخطيط له أولى من مفاجآته دون سابق توقع وتقدير، فنجاح الداعية في الغالب متوقف على قوة أو ضعف استشرافه للمستقبل، وذلك مما لا ينبغي الزهد فيه أو الاستغناء عنه، لأنّ

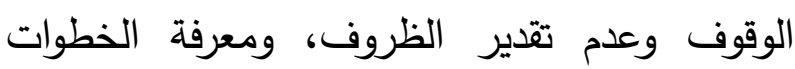
القادمة، أمر غير مقبول وهو فشل وتخبط: (والأجدر

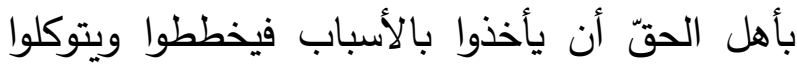

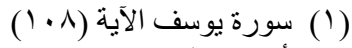

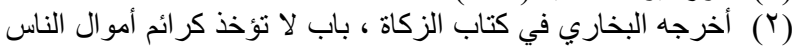

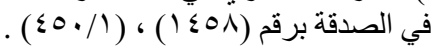


الدين ؛ للإحسان في الدعوة والتخطيط لها(؟) الذي

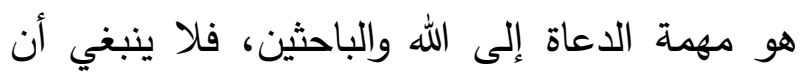

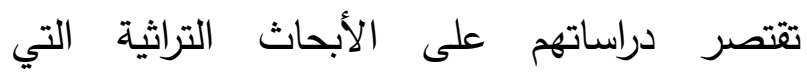

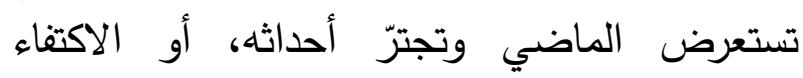

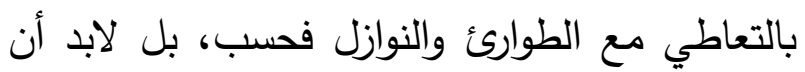
تتجاوز البحوث والدراسات الزمان والمكان؛ لتفتح آفاق المستقبل للدعوة والداعية، حتى يرسم خطواته، ويحدد خارطة طريق دعوته بمعالم مدروسة، وفقه أله

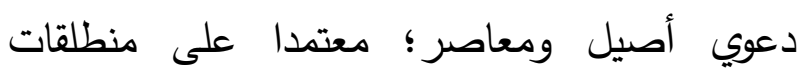

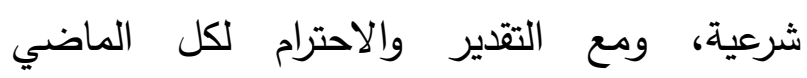
والحاضر لكن الاهتمام بالمستقبل لابدّ أن يكون الإنرام حاضرا دائما في ذهن الداعية، وظاهرا في جهوده

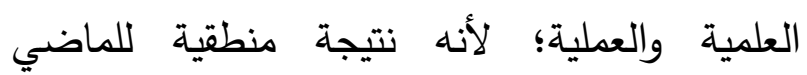
والحاضر •

وهذا الموضوع ليس كما يظن البعض أنّه من الرجم

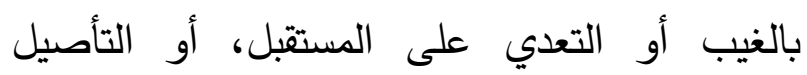

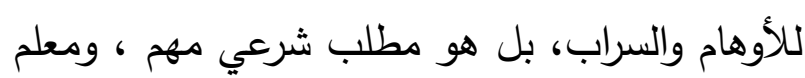

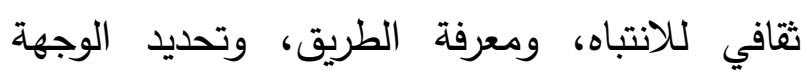

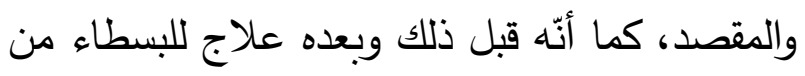
الوقوف مكتوفي الأيدي، والعيش في دوامة الحسابات

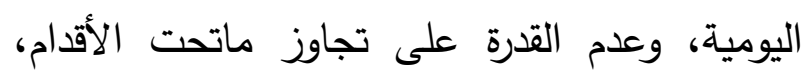

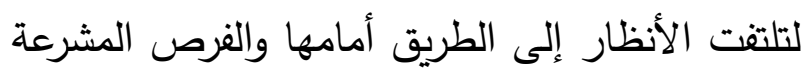

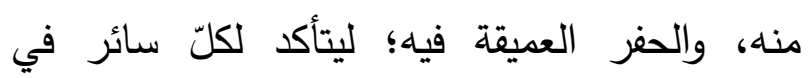

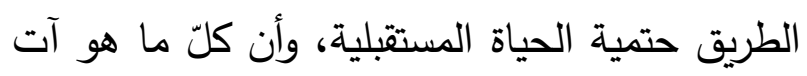

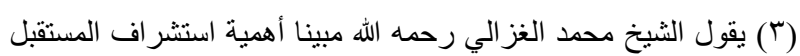

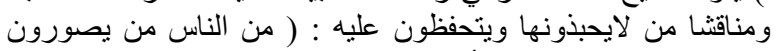

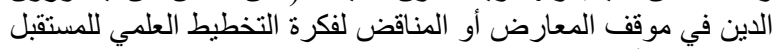

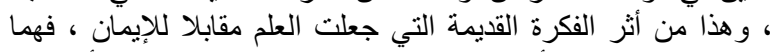

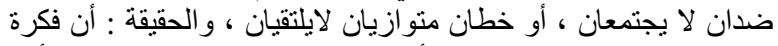

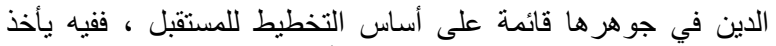

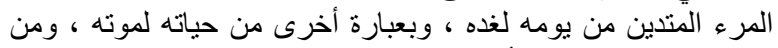

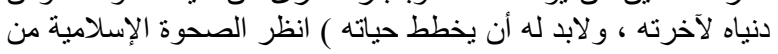

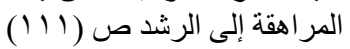

التي لا يمكن أن تستغني عنها الدعوة في هذا (') (العصر وقد وجد من الدعاة المخلصين من تأثر بواقع

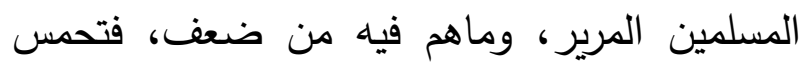

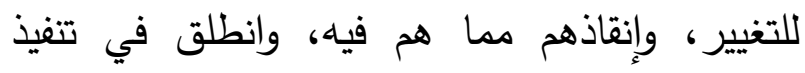

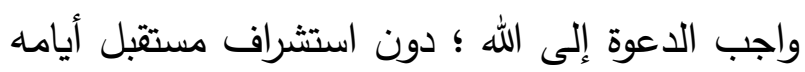

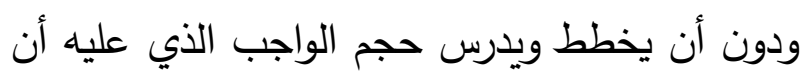

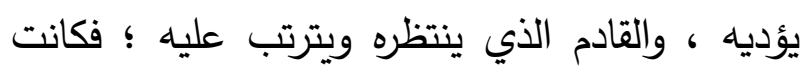

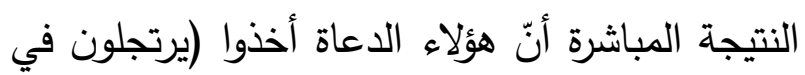

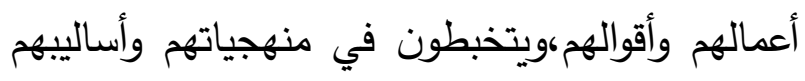

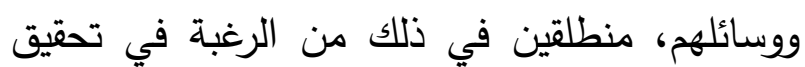

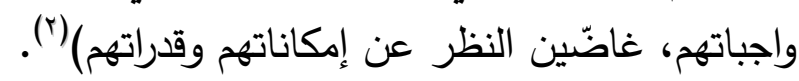

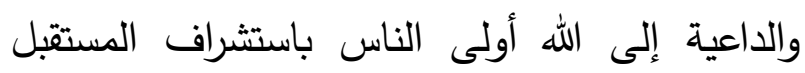

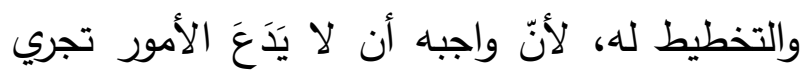

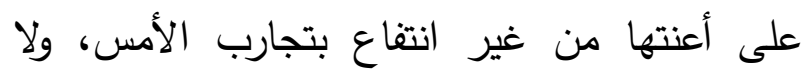

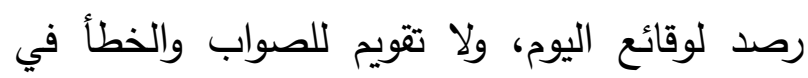

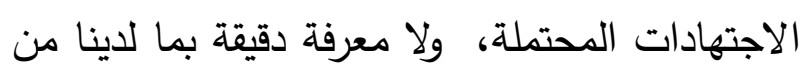

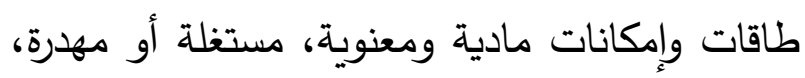

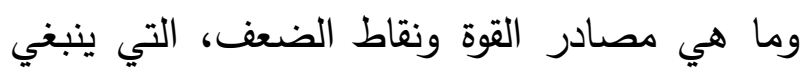
أن يقدرها، ويتحسب لها قبل وقوعها، ونحو ذلك من النظر والتأمل. ولا ينبغي أن يُفهم أنّ استشراف المستقبل والتطلع لمعرفته أمر شكلي، بل هو عين الفقه والبصيرة في أني

(1) الذي أصبح كل شيء فيه يؤسس على العلم و الثقلير والحسابات ، ولم

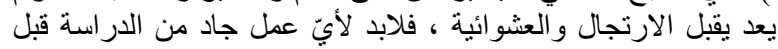

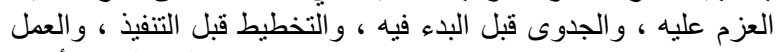

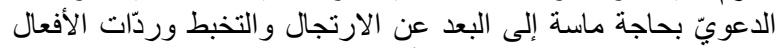

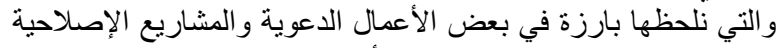

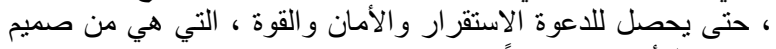

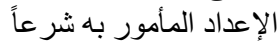

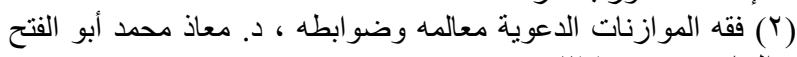
البيانوني صون (YT) 


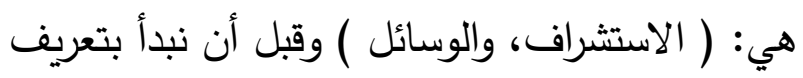

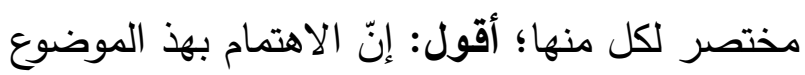

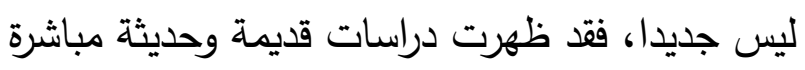

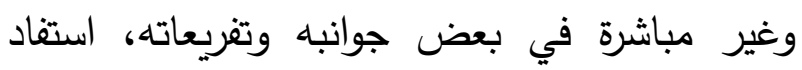
الباحث منها وانطلق من خلالها (1).

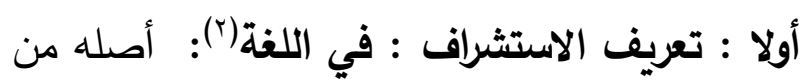

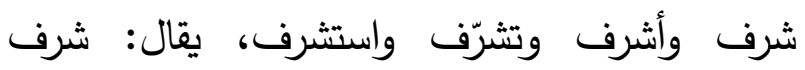

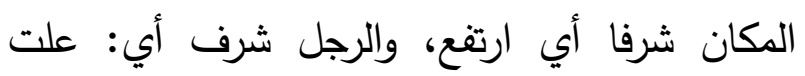

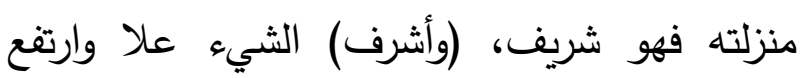

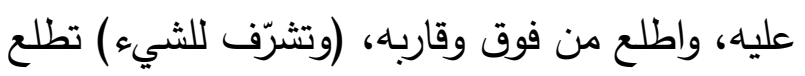
إليه، ومنه (تشرّف البناء) أي: جعلت له شرف، ألهاء ومعنى الفعل (استشرف) أي: انتصب: ولتبه وعلا، واستشرف الثيء أي: رفع بصره ينظر إليه، وتشرّف الثيء واستشرفه: إذا وضع يده على حاجبه كالذي لئي يستظل من الثمس حتى يبصره ويستبينه، وجاء في

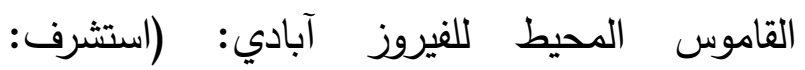

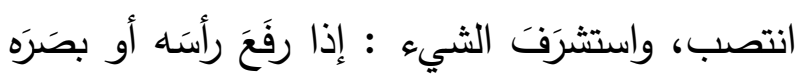
لينظرَ إليه)

الاستشراف في الاصطلاح: ومن خلال المعاني

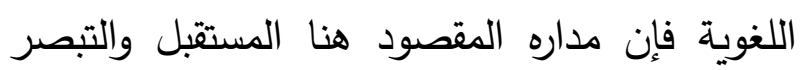
بأحداثه والألمعية والحدس والفراسة بما سيكون فيهان،

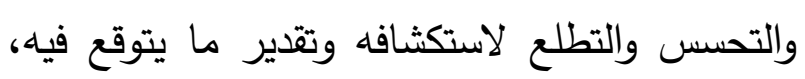

(1) ومن تللك الدراسات التي وقفت عليها ، وأفدت منها : [ الدراسات

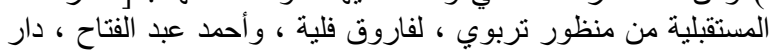

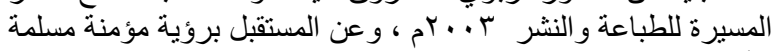

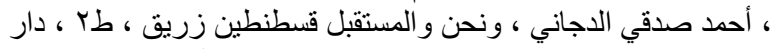

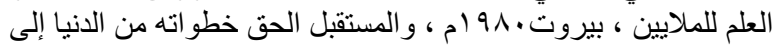

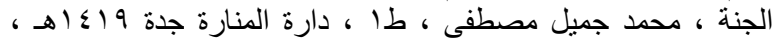

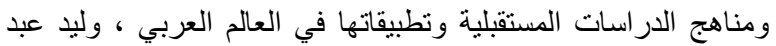

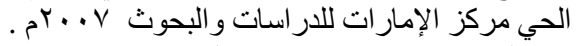

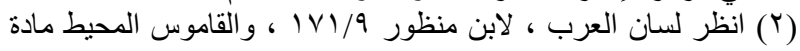

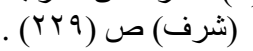

قريب، وأنّ العمل للمستقبل ليس أمرا فطريا دنيويّا فقط، بل هو أمر دينيّ جاءت النصوص النصوص الثرعيّة

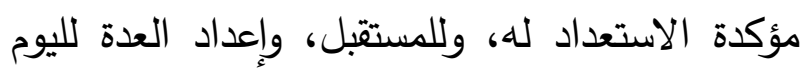
الآخر، وأنّ المصير في المستقبل مرهون بما قُّمّم في الحاضر والماضي.

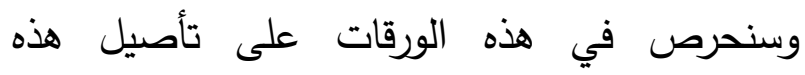
الحقيقة، وفقه شيء من معالمها، والوقوف على أبرز

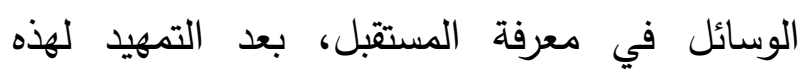

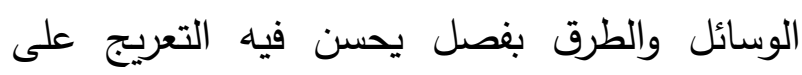

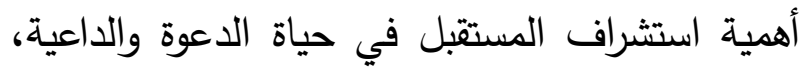
وإلا فإنّ موضوع استشراف المستقبل والتخطيط له؛

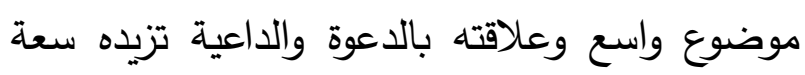

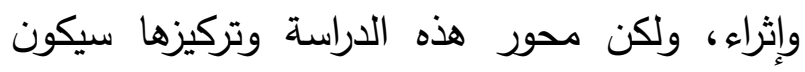

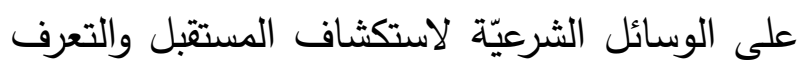
عليه وتجليته، وذلك بالتأمل في النصوص الثرئلئل الثرعية،

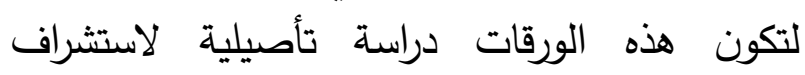

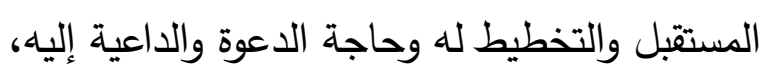

وتحت عنوان:

استثراف المستقبل والتخطيط له وحاجة الدعوة والداعية إليه دراسة تأصيلية في بيان أهميته ووسائل معرفته من خلال نصوص السنة النبوية - مدخل في التعريفات: لما كان الحكم على الثيء فرع عن تصوره كان

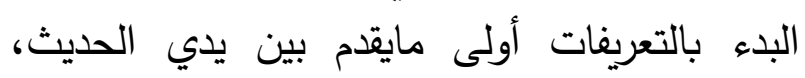
والمقصود من التعاريف ليس الحشو والاستطراد وإنما

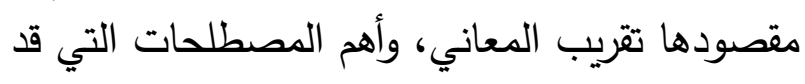
تحتاج إلى تعريف ومزيد بيان، وترتكز عليها الدراسة ولتهات المعات 


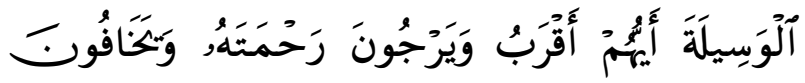

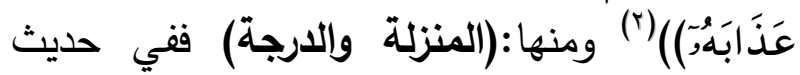

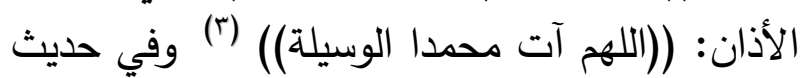
إجابة المؤذن : (( ثم سلوا الله لي الوسيلة فإنها منزلة الوانة

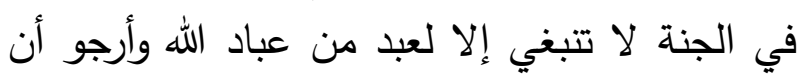

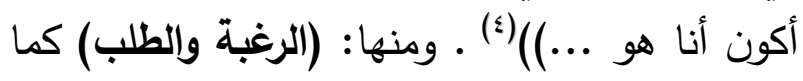
ذكره صاحب معجم مقاييس اللغة، بقوله: ( يُقال:

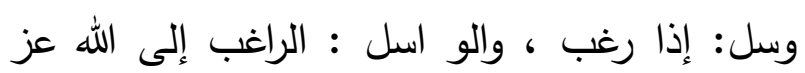
وجل )('ائل) الوسائل في الاصطلاح : حيث تتوعت وتعددت

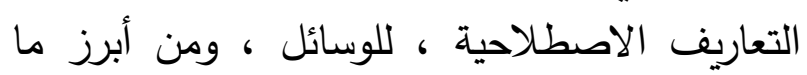

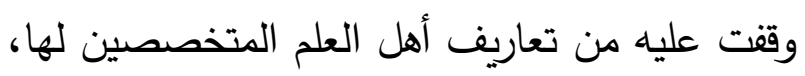

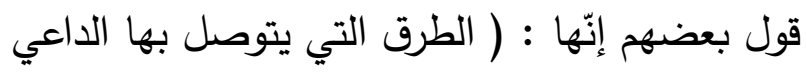

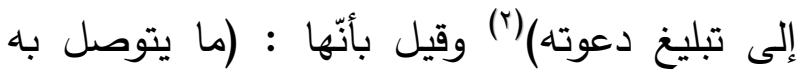

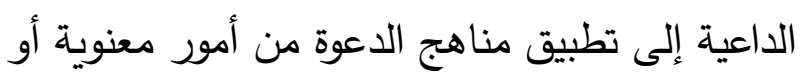

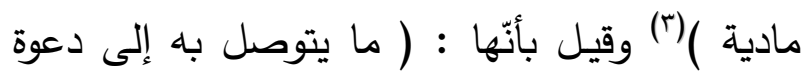

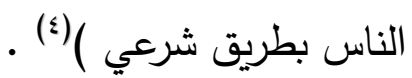
الفصل الأول :مقدمات في أهمية استشراف المستقبل

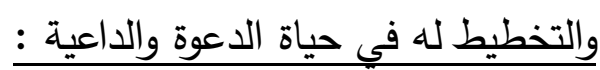

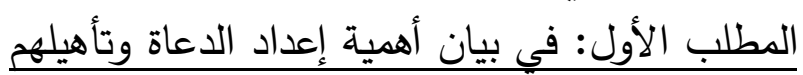

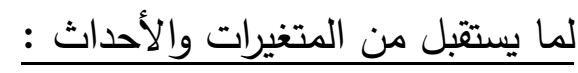

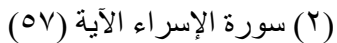

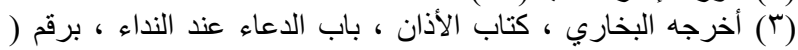

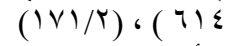

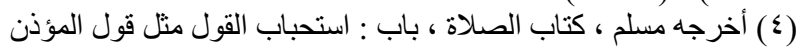

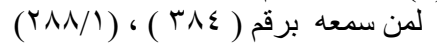

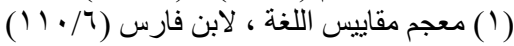

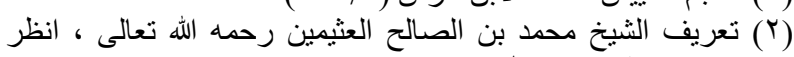

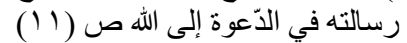
(ץ) تعريف الدكتور محمد أبو الفتح البيانوني ، النظر كتابه : المدخل إلى (الى (الى

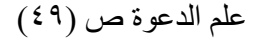
(ع) تعريف الدكتور عبد الرحيم محمد المغذوي انظر كتابه : وسائل

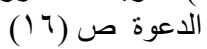

وما سيطرأ على الحاضر من متغيرات ومستجدات، فهو باختصار : ( توقع ما سيحدث في المستقبل) . وقد عرّفه المتخصصون بأنّه: (اجتهاد علمي مُنظقَّم، يرمي إلى صوغ مجموعةٍ من التوقُّعات المشروطة المئه

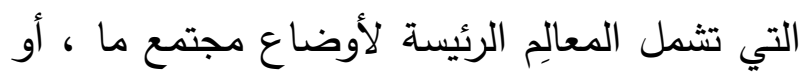

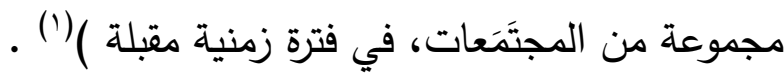
فهناك تلازم وتكامل بين استشراف المستقبل والتخطيط له، لأنّ التخطيط هو أحد العناصر

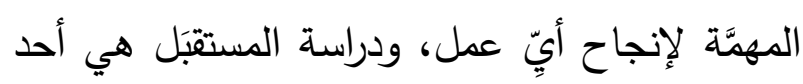

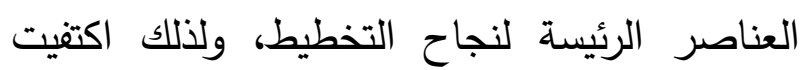
بتوضيح معنى الاستشراف لأنّه المقصود الأصيل

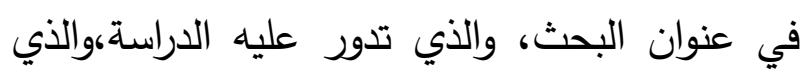
انتهى إليه المتخصصون في العلاقة بين المستقبل والتخطيط أنّ ( دراسة المستقبل خطوة سابقة لعملية التخطيط ، فهو تشوف واستطلاع وريادة، أما التخطيط فهو خطوة لاحقة، وهو توظيف لنتائج

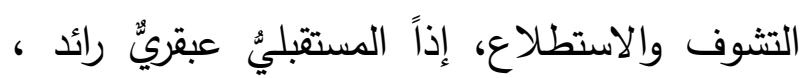

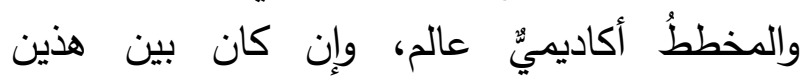

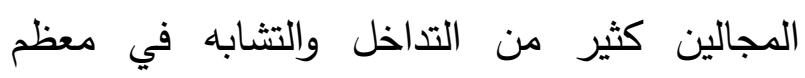

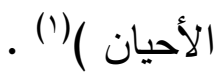

ثانيا: تعريف الوسائل: في اللغة: من الفعل (وسل)

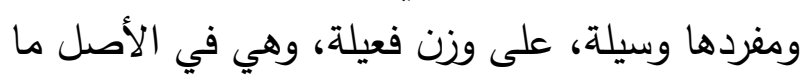

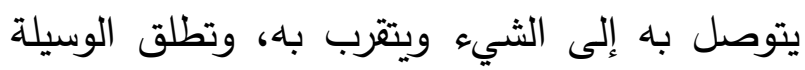
على عدة معان منها: (الوصلة والقربة) يقول الإمام

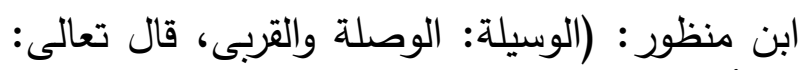

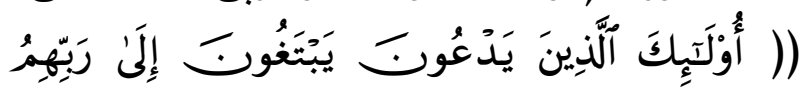

(1) انظر الدراسات المستقبلية من منظور تربوي ، لفاروق فلبة ، وأحمد عبد الفتاح ص (IV) (IV ) (1)

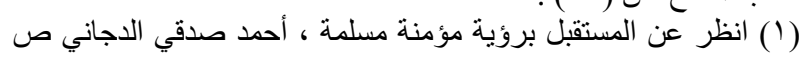


وقليل البضاعة ؛ فله أن يقوم بهذا الواجب بحسبه ، وعلى قدر استطاعته(r) بشرط أن لا يقول على الله بغير علم ، وأن يدعو إلى شيء يعلم حقه وصوابه ويحسن فيه ؛ حتى لوكان آية واحدة أو حديث ؛ فئ فعن ئن عبد الله بن عمرو هي ولو آية )(') فهذا النص الصريح في تبليخ الدعوة ؛

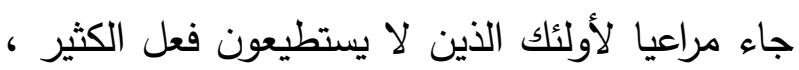
بل كل واحد بأقل ما يمكن ، وبحسب علمه وعلى هري

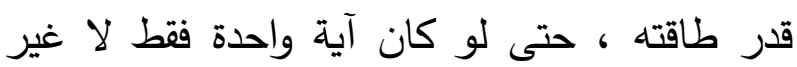
(إنما قال: آية ، أي من القرآن، ولم يقل حديثا فإن الآيات مع تكفل الله بحفظها واجبة التبليخ، فتبليخ

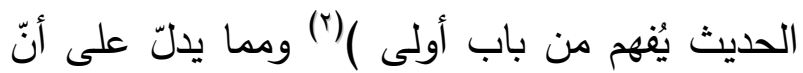

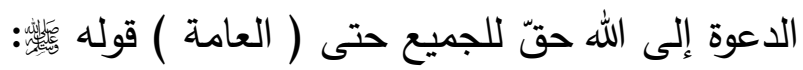

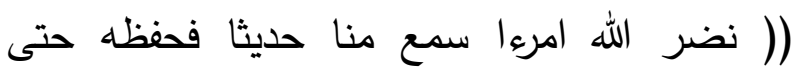
يبلغه، فرب حامل فقه إلى من هو أفقه منه، ورب

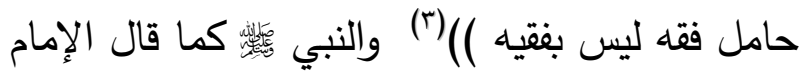
ابن القيم رحمه الله : ( دعا لمن سمع كلامه ووعاه وحفظه وبلغه، وهذه هي مراتب العلم الأربعة، فمن

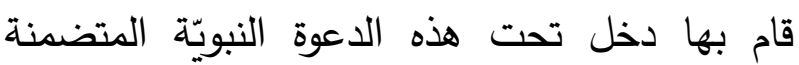

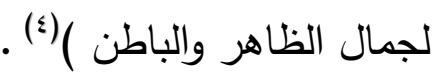

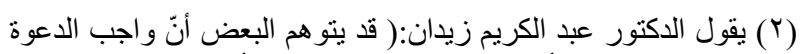

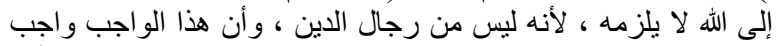

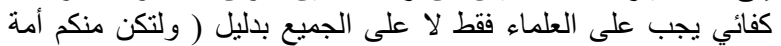

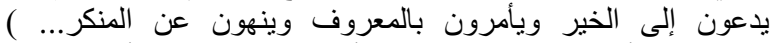

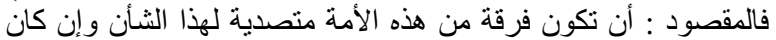

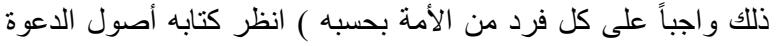

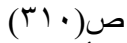

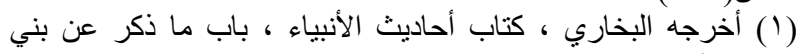

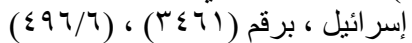

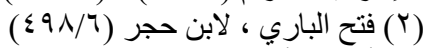

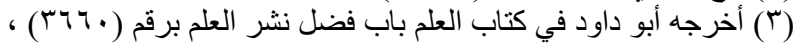

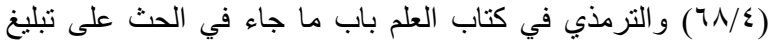

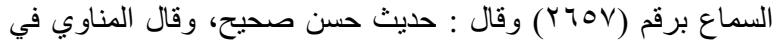

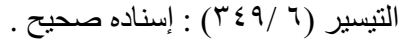

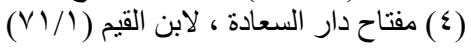

فالداعية إلى الله؛ هو الركن الأول والأهم من أركان

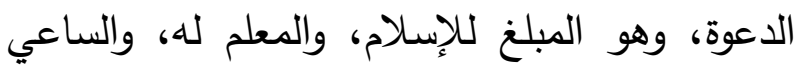

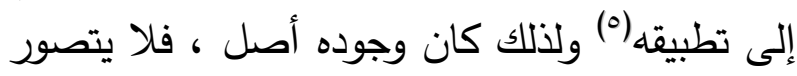

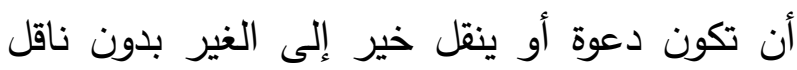
يقوم بذلك ، وكانت السنة الربانية ماضية في إرسال

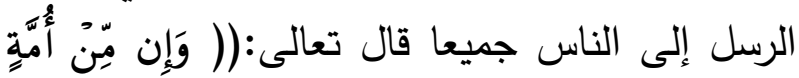

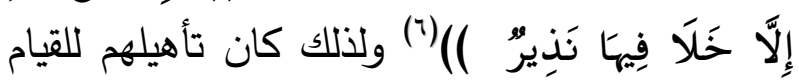

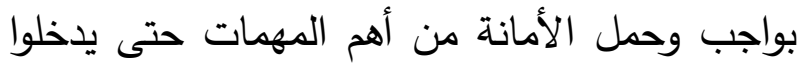

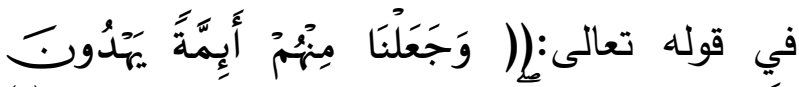

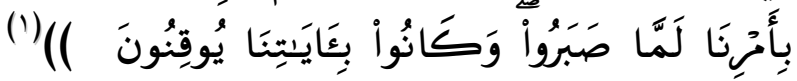
ومعنى أن يكون من الأئمة المهديين؛ أن يخلفوا النبي الدعوة ومسؤولياتها، بحسب علمه وقدرته وفقهاه، ويتفاوت حكم هذا الوجوب لاعتبارات كثيرة، ومن ونات وناته خلال هذا التفاوت يتنوع الدعاة القائمون بالدعوة، لألئات

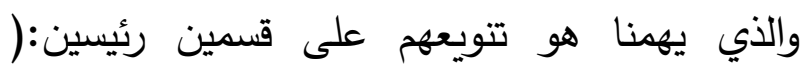

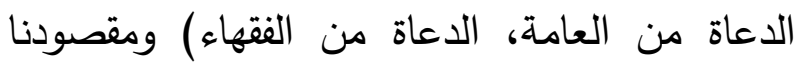
بهذا التقسيم بيان أنّ موضوع (استشراف المستقبل

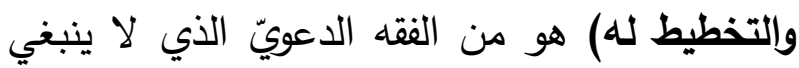

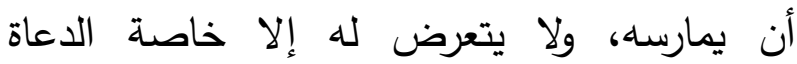
المؤهلين من العلماء والفقهاء وطلبة العلم، وللتفصيل في هذا التقسيم نقول : (1) الدعاة من العامة: فالدعوة إلى الله تعالى، رغم

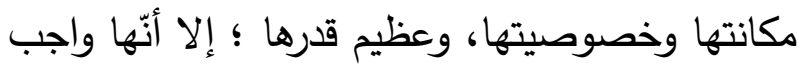

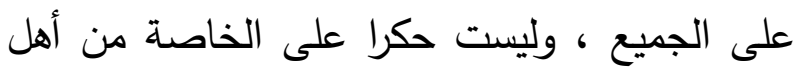

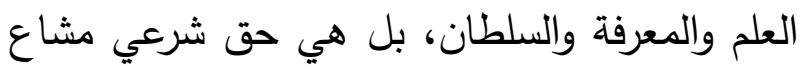

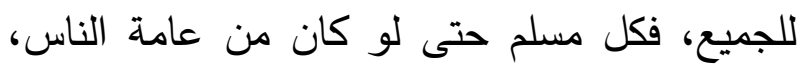

(0) المدخل إلى علم الدعوة ، للاكتور محمد أبو الفتح البيانوني ص ( • (؛)

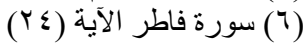
(1) سورة السجدة الآية (1) (Y) (Y) (1) 
يوجِّدوا الله تعالى ، فإذا عرفوا ذلك فأخبرهم أنّ الله قد

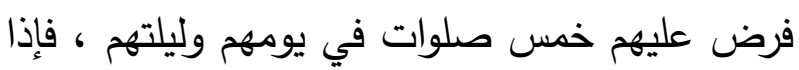

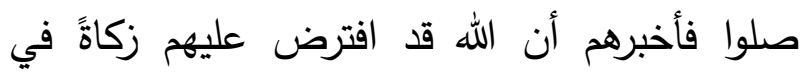

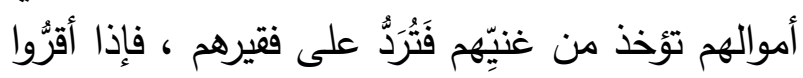

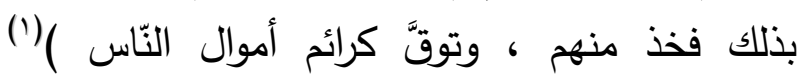
والحديث أصل واضح للدعاة إلى الله الذين يكلفون بالقيام بواجب الدعوة في تقدير ما سيقبلون عليه،

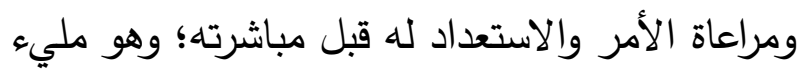

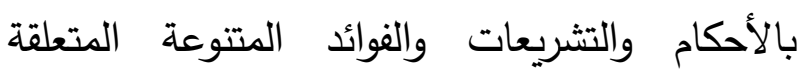

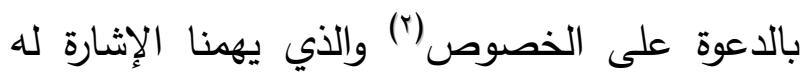
في هذا السياق ؛ كون الحديث جاء نصا في بيان

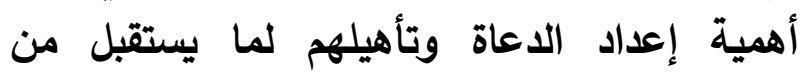

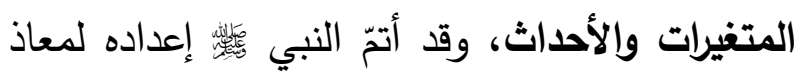

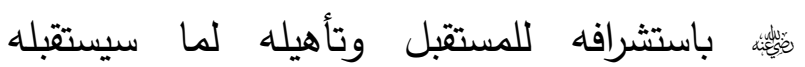

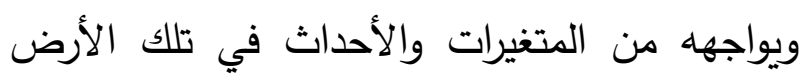
التي أرسله إليها ، ونبها إلى أهمية تحديد نقطة الهي

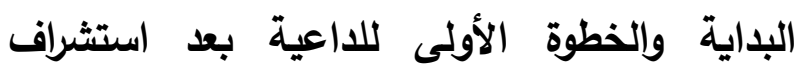
المستقبل: لأن الداعية إلى الله يلزمه قبل أن يخوض الألها

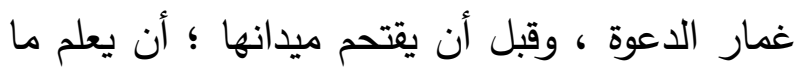

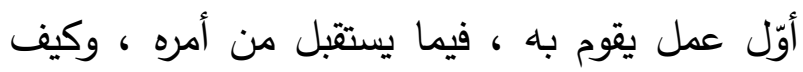

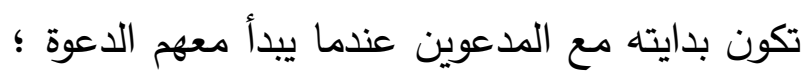

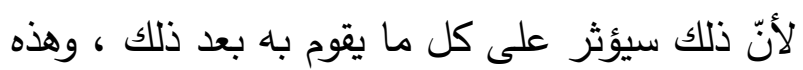

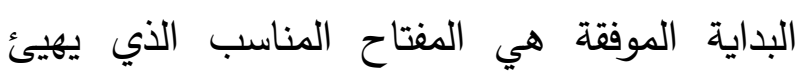

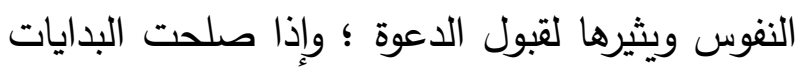
صلحت النهايات، وفي هذه الوصيّة لمعاذ بن جبل

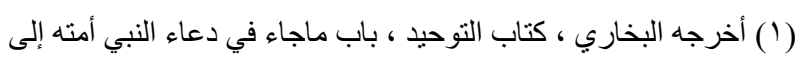

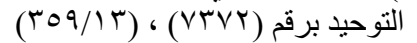

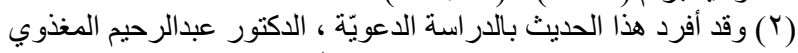

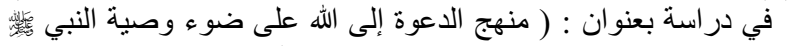

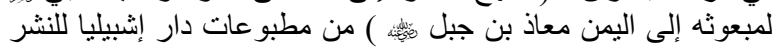

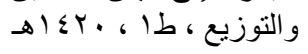

(Y) الاعاة من الفقهاء: فالعلم بالأحكام الشرعية،

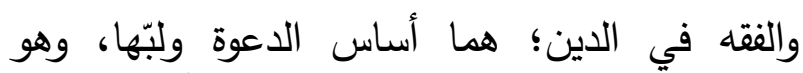

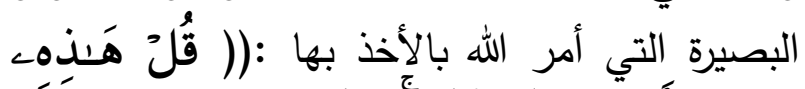

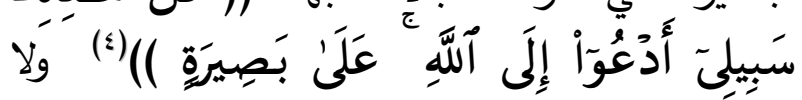
تحصلَ هذه البصيرة المأمور بها ؛ إلا بالعلم والفئه

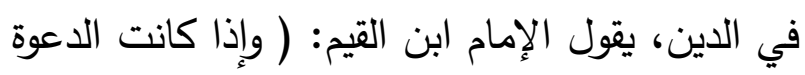

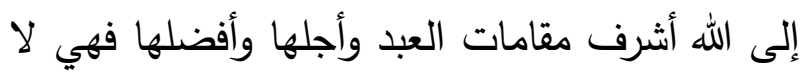
تحصل إلا بالعلم الذي يدعو به وإليه، ولابد من النابن

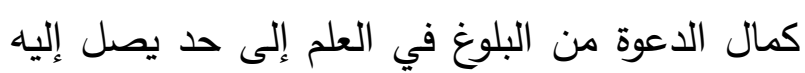

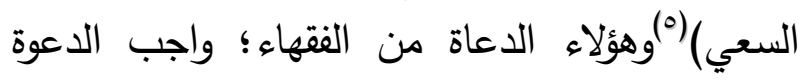

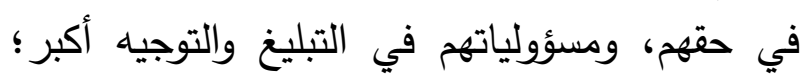

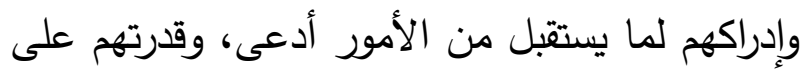

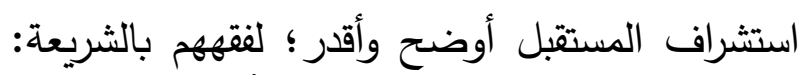

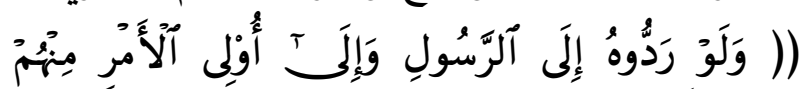

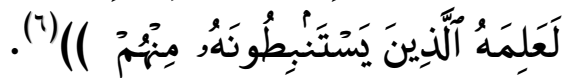

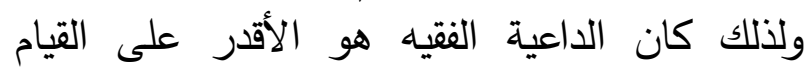
بواجب الدعوة ؛ لما يمتلكه من قدرات وإمكانات وسعة أفق وبعد نظر؛ أساسه العلم والتقوى؛ فنجاح الداعية في دعوته متوقف على دقة فهمه وفقها وبصيرته، حتى تؤتي الدعوة أكلها وتظهر ثمارها؛ دوته دئه

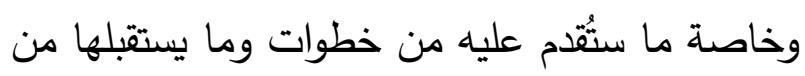
متغيرات؛ لأنّ معرفة المستقبل واستشرافه؛ فقه دقيق مطيق

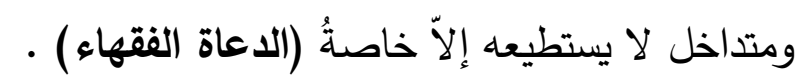

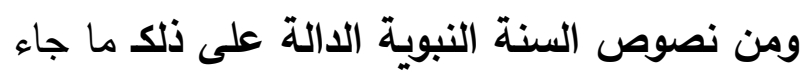

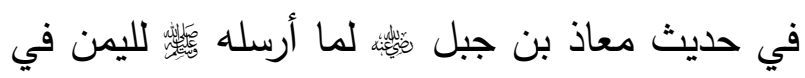

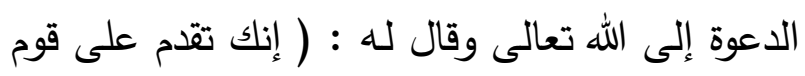
من أهل الكتاب، فليكن أوّل ما تدعوهم إلى أن أن إلى قأل 
فإذا استشرف الداعية مستقبل دعوته، واتضحت الرؤية فيما سيكون، وتزاحمت عليه التكاليف والمهمات، فسيقدر قبل الثروع في العمل والدعوة أيّ الأعمال يبدأ به؛ لأنّ الأعمال بطبيعتها فيها تفاوت، وفيها أعلى وأدنى، وفاضل ومفضول، وركن لأن الأن وواجب ومستحب، وأهم ومهم ، يقول الإمام ابن القيم رحمسـه الله تعالى: (والأفضل في وقت حضور الضيف مثلاً القيام بحقه والاشتغال به عن الورد المستحب، وكذلك في أداء حق الزوجة والأهل، والأفضل في أوقات السحر: الاشتغال بالصلاة والقرآن والدعاء والذكر والاستغفار، والأفضل في أوقات الأذان: ترك ما هو فيه من ورده والاشتغال بإجابة المؤذن ، والأفضل في أوقات ضرورة المحتاج إلى المساعدة بالجاه ، أو البدن أو المال: الاشتغال بمساعدته، وإغاثة لهفه، وإيثار ذلك على أورادك وخلوتك ... والأفضل في العشر الأخيرة من رمضان: لزوم المسجد فيه والخلوة والاعتكاف، دون التصدي لمخالطة الناس والاشتغال بهم،حتى إنه أفضل من الإقبال على تعليمهم وإقرائهم القرآن...فالأفضل في كل وقت وحال: إيثار مرضاة الله في ذلك الوقت والحال ، والاشتغال بواجب ذلك ولك

الوقت ووظيفته ومقتضاه )(') لذلك كان من أهم ما يؤهل الدعاة لما يستقبل من ومن المتغيرات، استشراف المستقبل واستكشاف بيئة الدعوة وأفرادها، وتقدير نقطة البدء الأولى معهم ؛

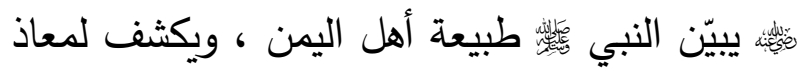

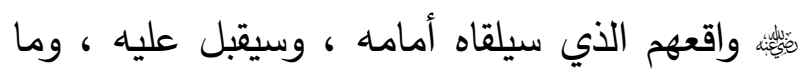
سيراه من المدعوين هنالك في مقتبل الأيام ، وما يناسب البداية به معهم وهو (الشهادتين) لأنّ ذلك هين سيسهل كلّ ما بعده ؛ لأنّ الإنسان إذا استشعر لإنه

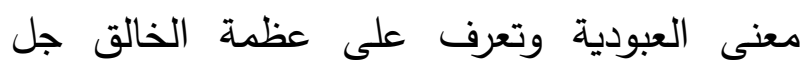

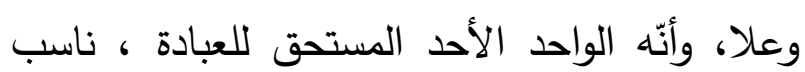
بعد ذلك أن يُكلّف شيئا فثيئًا بالعبادات والأحكام والتشريعات الأخرى التي يقوم عليها لالإسلام؛ كالصلاة والزكاة، فالمدعو لا يتقبل التكاليف ولا يضحي بثهواته وملذاته مالم يترسخ الإيمان في قلبه، يقول الإمام ابن حجر رحمه الله : ( ووقعت لإن البداءة بهما -أي الثهادتين- لأنهما أصل الآيّين الذي لا يصح شيء إلا بهما )(') .

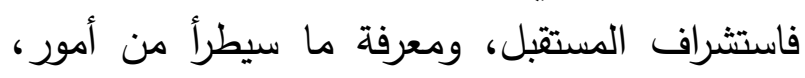
وستجدّ من متغيرات، مهم جدا في تحديد نقطة معنة البدء، والدعوة إلى الله تعالى يجب أن تركز على على الكل، وتبدأ بالأولى والأهم وهو الإيمان والتوحيد وتقدير الظرف واستشراف المستقبل الذي يدفع الداعية للبداية بما هو أنسب وتقديمه على غيره، لايعني إهمال غيره وعدم العناية به، فليس معنى هوليه البداية بهذه الأصول والمهمات إهمال بقية أمور الدين أو التقليل من شأنها، أو دعوى أنها أمور شكلية وقشور، فدين الله عقائده وأحكامه وتشريعاته

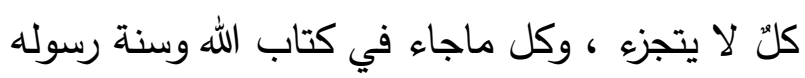

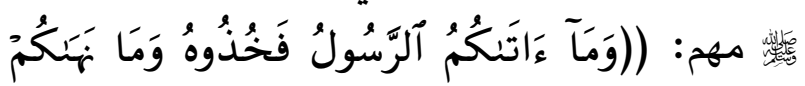

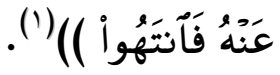


الوقوف على ذلك في المنام والأخبار من الكهان في قصدهم بمثل ذلك من الملوك و السوقة معروفة،

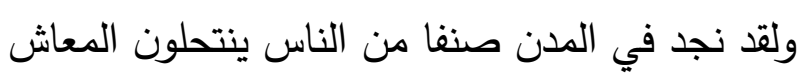
من ذلك لعلمه بحرص الناس عليه فينتصبون لهم في الطرقات والدكاكين يتعرضون لمن يسألهم عنه، فتغدو عليهم وتروح نسوان المدينة و صبيانها وكثيرٌ من ضعفاء العقول يستكشفون عواقب أمرهم في الكسب والجاه و المعاش والعشرة والعداوة وأمثال

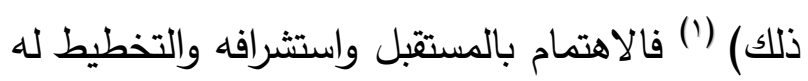
قديم قدم البشرية، ولكنّ ظهوره كعلم مستقل له له بله

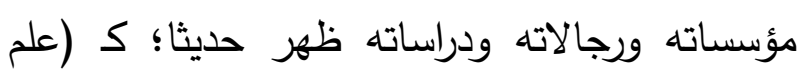
للمستقبليات)(r) وهو من أحدث العلوم عند الغرب، ودراته

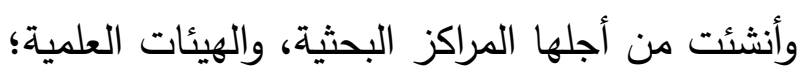
لما يشكله المستقبل من هاجس مخيف يحسبون له له لهربه ألف حساب خاصة مع نظرتهم المادية وغياب لئل الإيمان بالغيب في حياتهم.

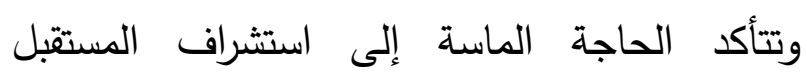
ومعرفة وسائل ذلك في هذه الأزمان التي أصبح كلّ المّلة ما فيها يبنى على الدراسات المستقبلية، والرؤية

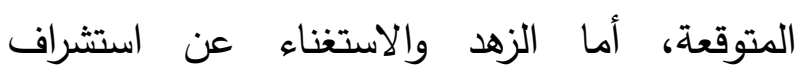

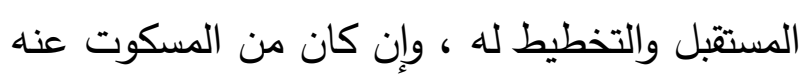

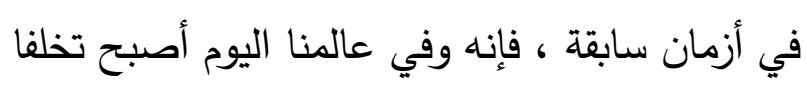

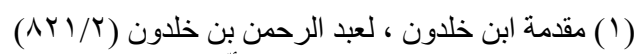

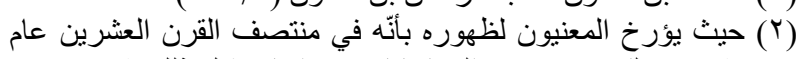

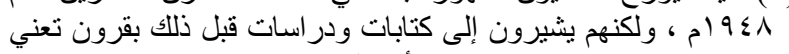

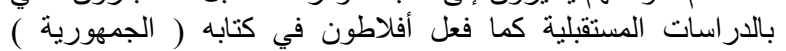

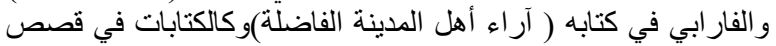

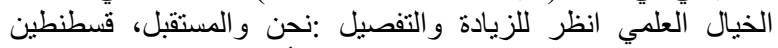
زريق صوף ، والدراسات المستقبلية وأهميتها للاعوة الإسلامية

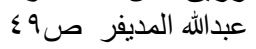

لأنّ البداية غير المناسبة بداية النفور من الدعوة والانحراف بها، واضطراب غير محمود يجعل الداعية

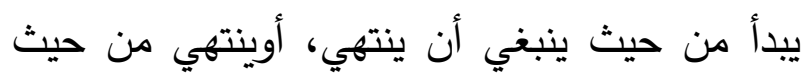

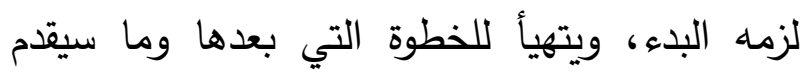

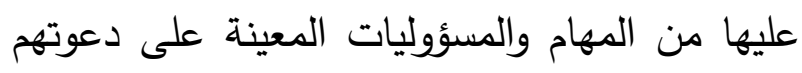
واستجابتهم. المطلب الثاني: في بيان أهمية استشراف المستقبل والتخطيط له وحاجة الدعوة والداعية إليه: العناية باستشراف المستثبل والاهتمام به لا يمكن أن

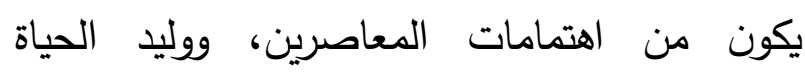
العصريّة ومستجداتها كما يتصور البعض؛ بل هون ونهاب

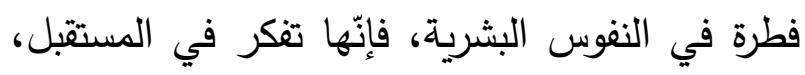

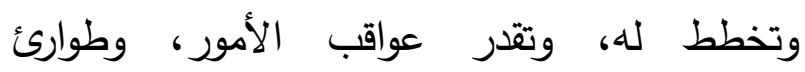

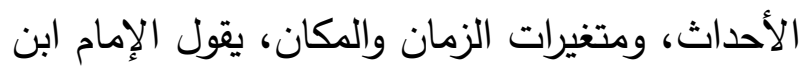

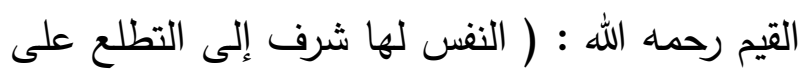

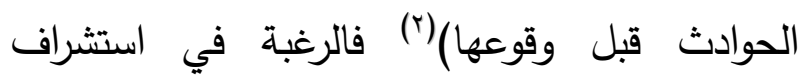
المستقبل من الغيب الذي تولع به النفوس ، وتحرص هابه

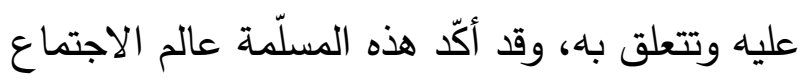

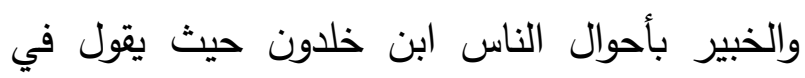
مقدمته رحمه الله: (اعلم أن من خواص النفوس البشرية التشوف إلى عواقب أمورهم و علم ما يحدث الهن

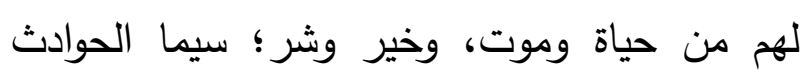

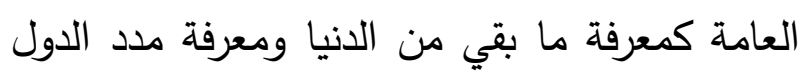
أو تفاوتها، فالتطلع إلى هذا طبيعة البشر ؛ مجبولون من التيان عليها ولذلك تجد الكثير من الناس يتشوفون إلى إلى 
بعدها، وبهذا الترتيب لتستكثف وتستشرف ما بعدها، فيكون التكليف الحاضر الأول، ممهدا للذي بعده ويهيئ لله ؛ لتتقبله النفوس وتؤمن به وتقتنع ، وهذا واضح كما أخبرت عائشة رضي الله عنها: (إنما نزل أول ما نزل من القرآن سور من المفصل فيها ذكر الجنة والنار حتى إذا ثاب الناس إلى الإسلام: نزل الحلال والحرام، ولو نزل أول شيء :لا تشربوا الخمر، لقالوا لا ندع الخمر أبداً ،ولو نزل :لا تزنوا، ولهول

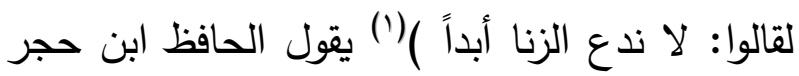
رحمه الله تعليقا: ( فلما اطمأنت النفوس على ذلك أنزلت الأحكام، ولهذا قالت:[ ولو نزل أول شيء: لا تشربوا الخمر لقالوا: لا ندعها ] وذلك لما طبعت عليه النفوس من النفرة عن ترك المألوف)(r) وهو ما

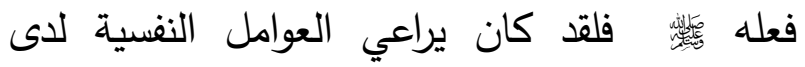
المدعوين؛ ويتشرف مستقبل أيامهم ليمهد لهم لتهيئة نفوسهم للقبول بما سيطرأ عليها، ويستجدّ في حياتها من تكليفات وتشريعات ، وهو نوع من التدرج واستشراف المستقبل، لترسيخ الدين وتتثيت المؤمنين (') ففي استشراف المستقبل ومراعاة المتغيرات وتوقع القادم؛ نوع من تهيئة النفوس البشرية وتغييرها لتقبل ما سيطرأ عليها، وما يستجد في حياتها مما لم تتعود

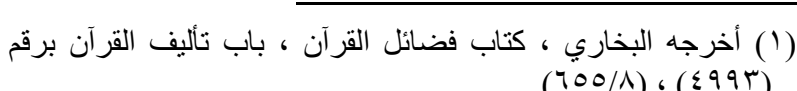

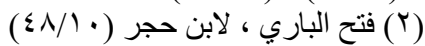

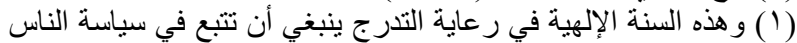

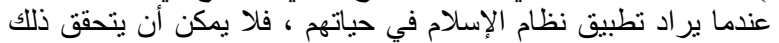

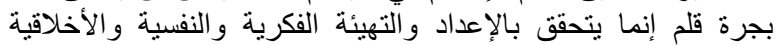
و الاجتماعية وإيجاد البدائل الثرعية للأوضاع الثياع التي كانوا عليها لأزمنة
غير مقبول، وتغريدا خارج السرب، وهذا الاهتمام المتأخر به، هو اهتمام متقدم سبقت إليه الأمة المحمدية، وأبرزته نصوص الوحي في الكتاب والسنة، لتخطو دعوة الإسلام بخطوات واثقة إلى الأمام دائما؛ وبلهجة صادقة لا تتكدر بالمتغيرات ولا تحرفها عن سيرها العواصف والمفاجآت؛ حتى يرث الله الأرض ومن عليها ('). وللدلالة على أهمية استثراف المستقبل في حياة الاعوة والداعية نذكر ما يلـي: أولا: في استشراف المستقبل تهيئة النفوس لقبول الحق وسماعه والاقتناع به: فتبليغ الإسلام والقيام بواجب الدعوة وحصولها والقناعة بها؛ لا يمكن أن يكون بين ليلة وضحاها، بل يحتاج إلى وقت ومراحل من التهيئة لحصوله، ولذلك استغرقت الدعوة المحمدية ثلاثا وعشرين سنة؛ لتقع موقعها، وتستقرّ في النفوس، وتكتمل حقيقتها وصورتها ؛ ولتصبح بعد ذلك دين الله الذي لا يقبل الله غيره ولا يرتضي سواه، ولذلك كان من المهم عند القيام بواجب الدعوة إلى الله ؛ تهيئة النفوس والأجواء لتكون مناسبة لعرضها ، حتى لا تكون أوّل ردة فعل منها هي الرفض والإعراض ، ولذلك كانت الحكمة واضحة من نزول القرآن منجما ومفرقا حسب الحوادث والوقائع والمستجدات ؛ كل فترة تمهّد للتي

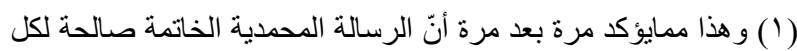

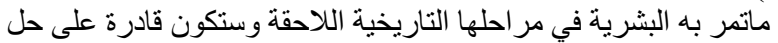

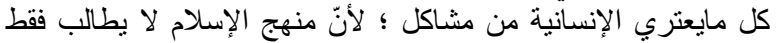

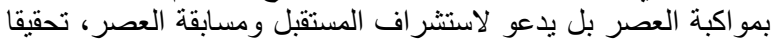
لهذا الواجب البة العبر 
الدعوة المتين وصرحها المتماسك، وكلّ من يريد

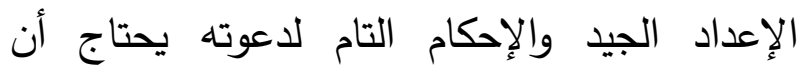
يتعرف على واقعه بدقة، ويستشرف مستقبله بصدق،

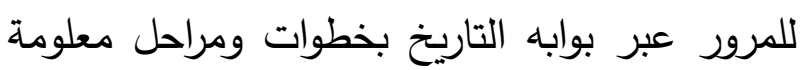
ومدروسة؛ وعلى ذلك قامت الدعوة الإسلامية الأولى؛ فكانت مستمرة وباقية وثمرتها وآثارها وأتباعها مستمرون إلى قيام الساعة ؛ ولو أنه فئس

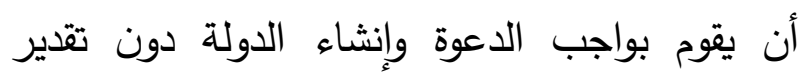
الظروف والمتغيرات والطوارئ ، ودون قراءة صحيحة للمستقبل؛ لما بلغت دعوته ما بلغت، ولا استطاع

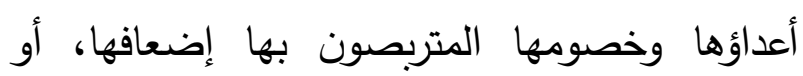

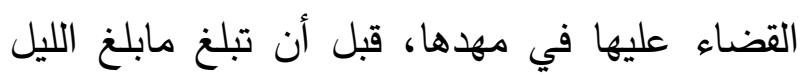

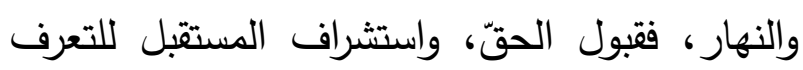

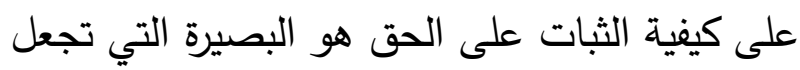

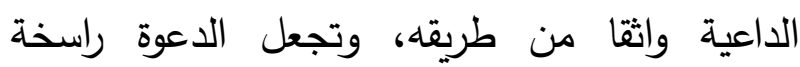
ومتجذّرة في النفوس ف::(الإنسان يطلب أولا تحصيل

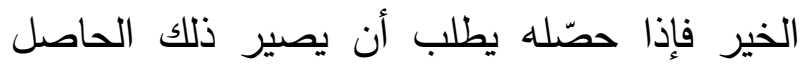

(') ثابتًا باقيًَا) وهذا التريث للوصول للكمال، وتحقيق الإحكام، وترسيخ المبادئ ؛ هو نتيجة منطقيّة لقراءة المستقبل

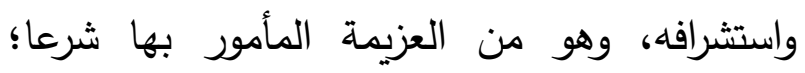
والمبنية على أصول محكمة، أمّا التسرع والعجلة والسرعة في الخطوات نحو المستقبل، وقطع الليالي والأيام، والفيافي والقفار ، دون استشراف لما سيكون

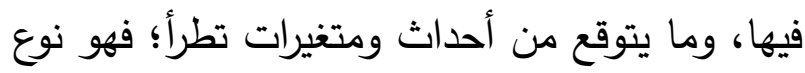

عليه، ويحتاج ذلك من الداعية إلى الله تعالى إلى جهد كبير ومركّز ؛ للتأثير على النفوس وتغييرها تغييرا منطقيا نحو الأصلح ؛ لأنه ليس من السهل أن أن

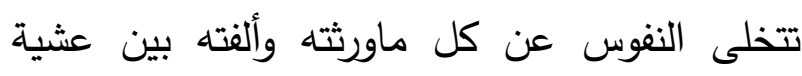
وضحاها، فكان من ثرات هذا الاستشراف للمستقبل

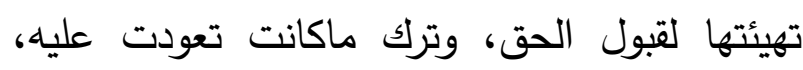
وهذا يحتاج إلى تدرج بها حتى تتعايش مع المستقبل القادم الذي سيصير في القريب هو (الواقع) يقول

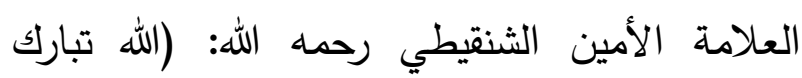
وتعالى لعظم حكمته في التشريع إذا أراد أن يشرع العاله أمرًا شاقًا على النفوس كان تشريعه له على فلى سبيل التدرج، لأن إلزامه بغتة في وقت واحد من غير تدرج

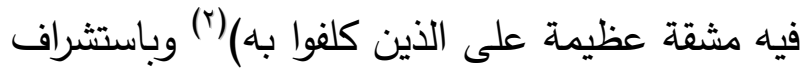

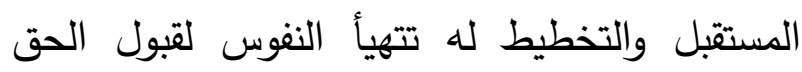
وسماعه والاقتناع به، ولا يكون عنصر المفاجأة الذي قد يؤدي للاستغراب وعدم التقبل . ثانيا: في استشراف المستقبل تحقيق الكمال والإحكام وترسيخ المبادئ: الذي يريد تشييد بناء متين، وصرح شاهق، يحتاج إلى خطوات مدروسة ومراحل متأنية، وأساسات يبني عليها بنيانه، وفقه الداعية في استثرافه المستقبل والتخطيط له يمكنّه من غرس المبادئ وترسيخها في

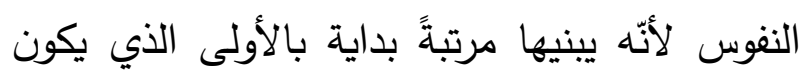

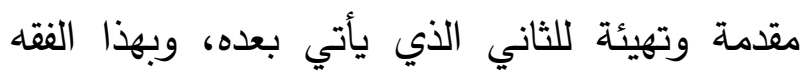

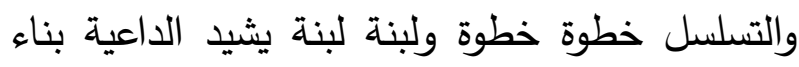


يأمن العبد طريق المغضوب عليهم الذين فسد

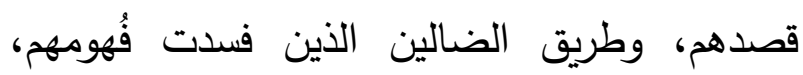
ويصير من المنعم عليهم الذين حسنت أفهامهم وطنئ وقُصودهم وصحة الفهم نور يقذفه الله في قلب العبد، يميز به بين الصحيح والفاسد، والحق والهدى وهري

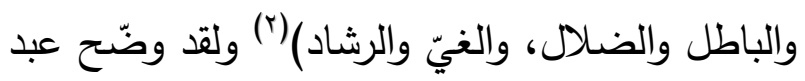

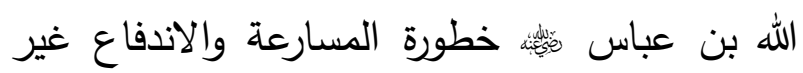
المدروس حتى لو كان في الخير ، حيث يقول: ( قدم

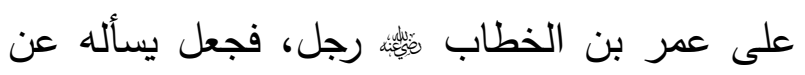
الناس ، فقال : يا أمير المؤمنين ، قد قرأ القرآن منهم كذا وكذا، فقال ابن عباس: والله ما أحب أن يسارعوا يوههم هذا فى القرآن هذه المسارعة، قال : فزجرنى عمر، وقال: مده، فانطلقت إلى منزلى كئياً حزيناً، فبينا أنا كذلك، إذ أتانى رجل فقالفال أجب أمير أمير

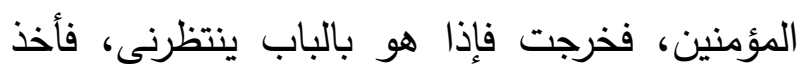

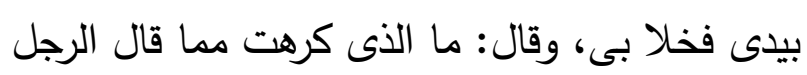
آنفاً ؟ فقلت: يا أمير المؤمنين : متى ما يسارعوا هذه

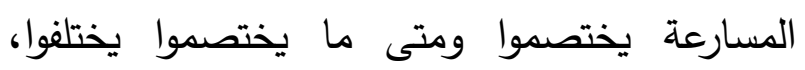
ومتى ما يختلفوا يقتتلوا ، قال الله أبوك، والله إن كنت لأكتمها الناس حتى جئت بها)(') ففي هذه الحادثة يتبين وبوضوح كيف أنّ المسارعة غير المدروسة وبدون قراءة للمستقبل واستشرافه ؛ حتى لو كانت في قراءة القرآن ودراسته مع أهميته ومكانته قد تُوقع في ولي لخلاف الذي قد يؤدي للقتال. ثالثا : حماية الدعوة والداعية ووقايتهر من العثرات والزلات:

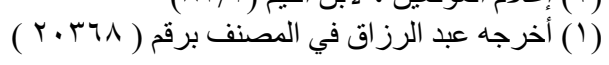

من الاندفاع غير المدروس وغير المحمود ف:

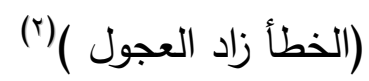
وكلّ من يتصدر للناس، وعلى رأس القائمة الدعاة إلى الله تعالى، لا ينبغي لهم السباحة مع التيار ولا الإقدام على الفعل، واقتحام المستقبل دون المعرفة الأكيدة؛ فهذا نوعُ من التسرع قد يترتب عليه الضرر الكبير لأنّ ذلك من العجلة التي يقول فيها الإمام ابن القيم رحمه الله: (طلب أخذ الشيء قبل وقته فهو لشدة حرصه عليه بمنزلة من يأخذ الثمرة قبل أوان إدراكها كلها؛ فالمبادرة وسط بين خلقين مذمومين، أحدهما: التغريط والإضاعة، والثاني: الاستعجال قبل الوقت، ولهذا كانت العجلة من الشيطان فإنها خفة وطيش وحدة في العبد تمنعه من التثبت والوقار والحلم وتوجب له وضع الأشياء في غير مواضعها

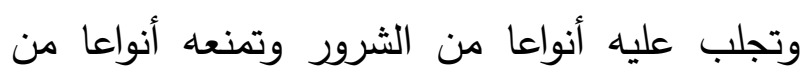
الخير ، وهي قرين الندامة ، فقلّ من استعجل إلا ندم

كما أنّ الكسل قرين الفوت والإضاعة )(') والتوثق وتمام الفهح ووضوح الرؤية، قبل الإقدام على المستقبل من خلال استشرافه والتخطيط له وتقدير الظروف والطوارئ والمتغيرات هو المطلوب الذي يتحقق به الكمال والإحكام، وتترسخ هن ولطيرات

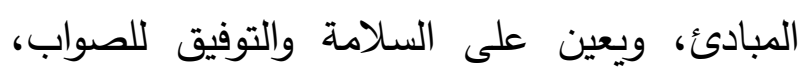
يقول الإمام ابن القيم رحمه الله: (صحة الفهم وحسن القصد من أعظم نعم الله التي أنعم بها على عبده،

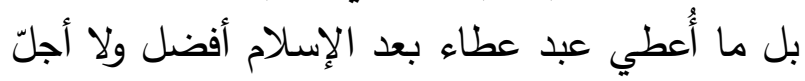
منهما،بل هما ساقا الإسلام، وقيامه عليهما، وبهما ليعاء

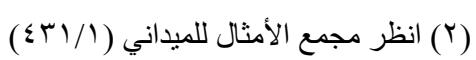
(1 (1) الروح ، لابن القيم ص (Y01) 
عن الراجح، وبالمحبوب له عن الأحب إليه،وبالمرضي عن الأرضى لله، فإن نجا منها بفقه

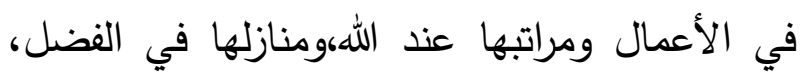
ومعرفة مقاديرها، والتمييز بين عاليها، وسافلها،

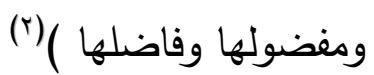
الفصل الثاني: طرق ووسائل استشراف المستقبل والتخطيط له وحاجة الدعوة والداعية إليها : الوسائل للوصول للغايات كثيرة ومتتوعة، وهذه الوسائل المتنوعة لها خصائص وميزات كثيرة من المهم التعرض لها وإبرازها، وذلك للتثريق بين وسائل

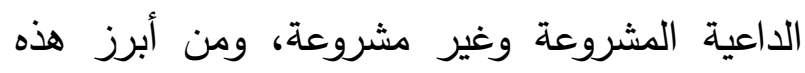
الخصائص التي يحسن التمهيد بها قبل التفصيل في وعير فئروني وسائل استشراف المستقبل وطرقه: (شرعيّة هذه ئهي الوسائل) وانضباطها والتزامها بالأحكام الإسلاميّة، وعدم خروجها عن الشريعة، وأن تكون نابعة من

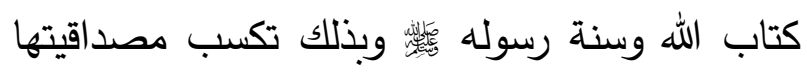

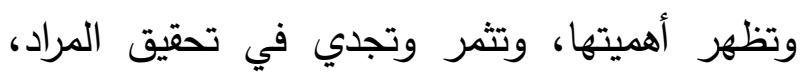

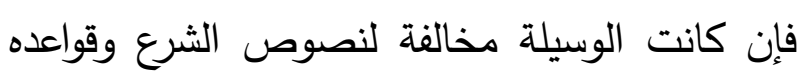
العامة فلا يشرع التوسل بها إلى المقاصد والغايات، ولن تحقق المقصود يقول شيخ الإسلام ابن تيمية رحمه الله: ( ليس كلّ سبب نال به الإنسان حاجته يكون مشروعاً ولا مباحاً، وإنما يكون مشروعاً إذا غلبت مصلحته على مفسدته، مما أذن فيه الشرع)(") والدعوة هي إلى الله ووسائلها ينبغي أن تكون على هلى مراد الله، والغاية في الإسلام لاتبرر الوسيلة وفي

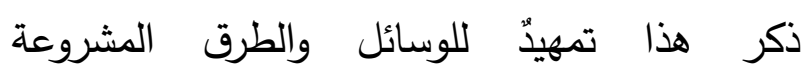

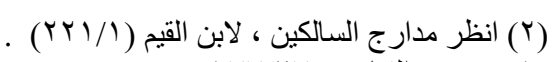

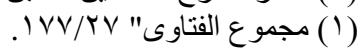

الدعوة معرضة للعثرات والزلات، وذلك عندما يتعرض الداعية لها، ولكنّ الله يحميه من ذلك ومن غيره بفقه دعوته واستشراف مستقبلها، والرؤية الواضحة في خطواتها وما ستقبل عليه، ويزيد الدعاة إلى الله حفظا وحماية لهح ولاعوتهم من العثرات والزلات إدراكُهم ما في استشراف المستقبل والتخطيط له من المكاسب التي تجنبهم الآثار والعواقب الوخيمة، والخطوات الارتجالية ؛ البعيدة عن الحكمة والبصيرة، مما قد يوقعهم فيما لا تحمد عقباه من ولان فثل وندم على ما فات لهم ولاعوتهم، ويقفون

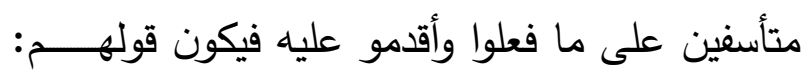
لو استقبلنا من أمرنا ما استدبرنا لما فعلنا كذا، وأهو ولتهيأنا بكذا ، ولسألنا عن كذا ولقدّرنا فعل كذا. ومن أبرز ما يحصل فيه الخطأ والخلل، ويهم الدعوة ويحتاج الدعاة للانتباه له؛ تشتيت جهودهم عن ين القضايا المهمة والأصيلة التي توصلهم للهدف والمقصود، إلى بنيّات الطريق التي تحرفهم عن الطريق وتشغلهم عن السير إلى الله(!) فاستشراف المستقبل ومعرفته يسهل على الداعية حسن التقدير

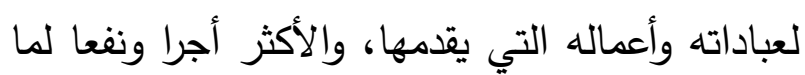
يستقبل من الأيام، ويكون أقدر من غيره وأفقه في مواجهة الشيطان ومكايده حتى لايزين له أمرا أدرك ولك عدم أهميته، أو يشيّنه وقد أدرك أهمية فعله ، لأنّ الشيطان يشغله (بالمفضول عن الفاضل، وبالمرجوح

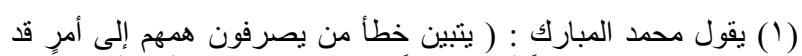

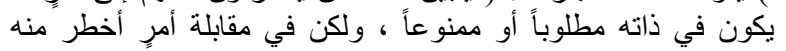

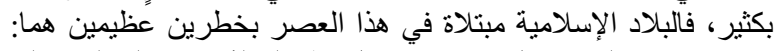

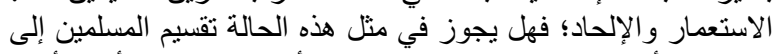

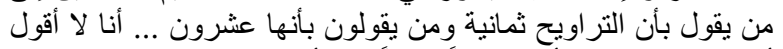

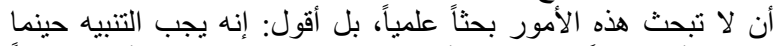

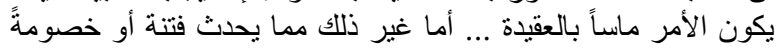

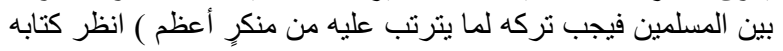

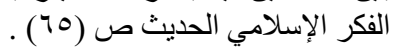


على رأس وسائل وطرق معرفة ما قد يحصل في المستقبل واستشرافه ؛ وهي الطريقة الأولى والمباشرة؛ أن ينصّ الوحي عليها، حيث جاءت كثيرا من وهن النصوص الشرعيّة كاشفة للمستقبل ، ومبينة بوضوح لما سيحصل فيه من أحداث ومتغيرات، فالنص على ذلك في القرآن أو السنة طريق أصيل ومباشر في معرفته والدلالة عليه، ولذلك كان من المهم لمن يريد معرفة المستقبل واستشرافه العيش مع نصوص القرآن والسنة واستخلاص ما أشارت إليه في هذا المعنى

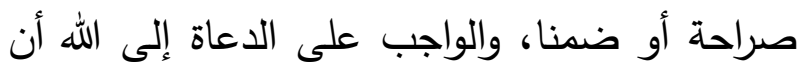
ينطلقوا من نصوص الوحي وأن يربطوا تخطيطهم

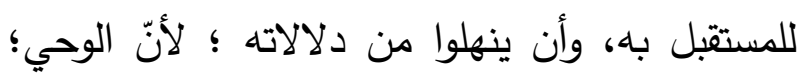

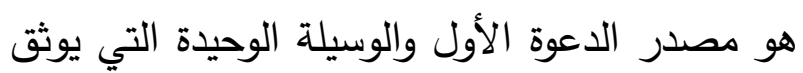
بها في قراءة المستقبل ، وتوقع ما سيكون وما سيواجهه الداعية ويتعرض له في مقتبل عمره، وقد

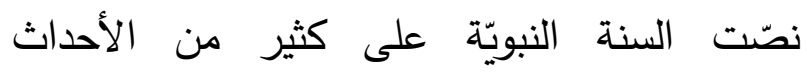
المستقبلية التي ستقع، وكثفت كثيرا من المتغيرات القادمة، وحذّرت بناء على ذلك من فعل أمور، أو

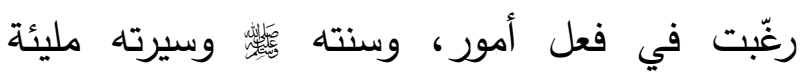
بالإشارة للمستقبل وبيانه والدلالة عليه صراحة أو ضمنا، فالقرآن والسنة هما الوسيلة الأولى والطريق ولئه الأقصر والأوثق لاستشراف المستقبل.

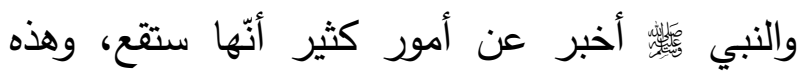

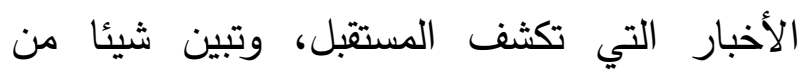
الوقائع والأحداث التي ستقع قبل وقوعها، ويطلق

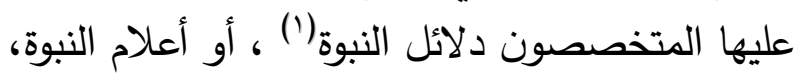

(1) وفي كتاب دلائل النبوة للبيهقي رحمه الله ، و غيره من كتب السير

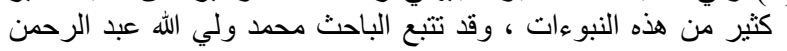

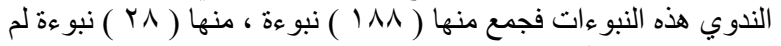

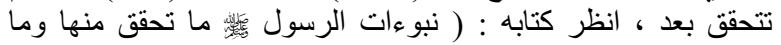

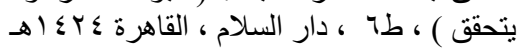

لاستشراف المستقبل(r) وتتبيهُ لكل أولئك المعتدون والمفتئتون الذين يحاولون استشراف المستقبل وكشف ولف ستاره بوسائل يحظرها الثرع ويمجها العقل، فتراهم يلهثون وراء الكهان والمنجِمِين، وآخرون يعتقدون في الأبراج السماويّة، ويتلاعب بهم البطالون بالخط والرمل وقراءة الكف ونحو ذلك مما هو محرم

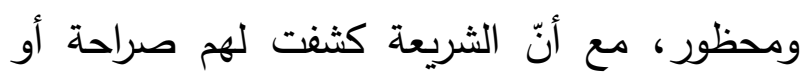
ضمنا كثيرا مما يحتاجونه في مستقبل أيامهم، وأرشدتهم إلى وسائل مشروعة لاستشراف المستقبل، بل هيأ الله لهم في يقظتهح ومنامهح ما يساعدهم في ذلك.

واستشراف المستقبل وحسن التخطيط لله لا يحصّله إلا من أكرمه الله بالبصيرة في الدين، والفقه في وحني

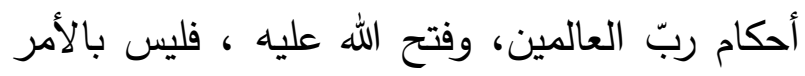
الهين؛ ولذلك ينبغي للداعية إلى الله أن يسير وفق ولى اله طرق شرعية، ومنهج ربانيّ، وفقه دعويّ ، بعيدا عن لن إني الهوى والرغبات، والطوارئ والمداخلات ليتمكن وبدقة

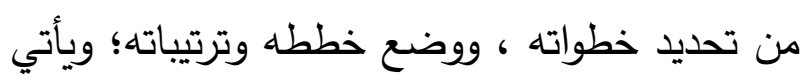

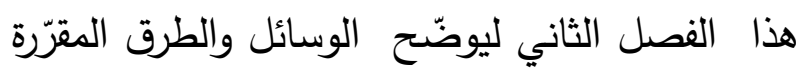
للوصول لمعرفة المستقبل وقراءته واستشرافه، وهي كثيرة ولكني أكتفي في هذه العجالة بستة منها فقط هـي: المطلب الأول : التنصيص عليها بالوحي بورودها في القرآن والسنة :

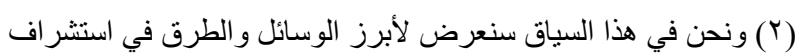

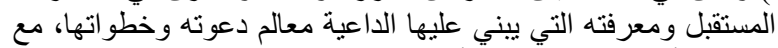

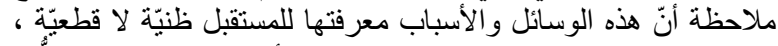

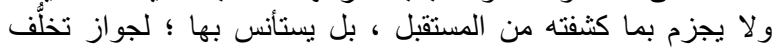

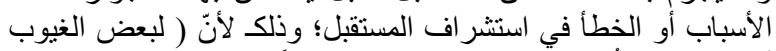

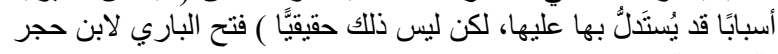

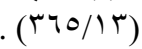


- ما جاء عن حذيفة رضي الله عنه قال : (( قام فينا رسول الله ذلك إلى قيام الساعة إلا حدث به ، حفظه من حفظه

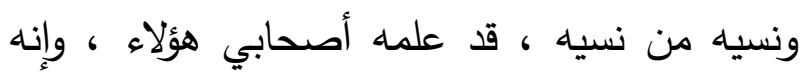
ليكون منه الثيء قد نسيته فأراه فأذكره كما يذكر فئه الرجل وجه الرجل إذا غاب عنه ثم إذا رآه عرفه )(') - ومن ذلك ما جاء عن أبى هريرة رضي الله عنه الته

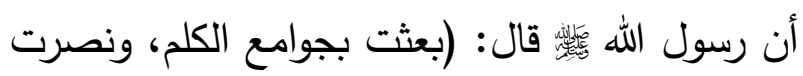

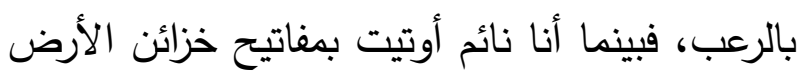
فوضعت في يدي ) قال أبو هريرة رضي الله عنه :

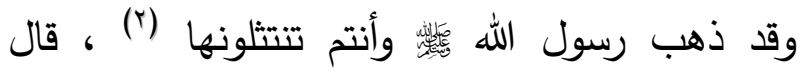
الإمام النووي رحمه الله عند هذا الحديث : ( وهذا

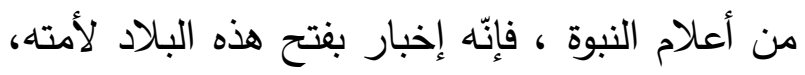

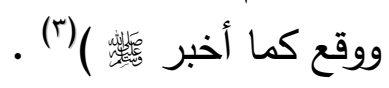
- ومن ذلك ما جاء عن أبى هريرة رضي الله عنه أن رسول الله

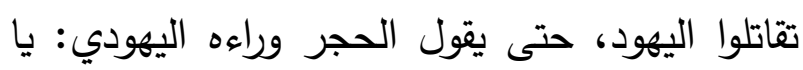

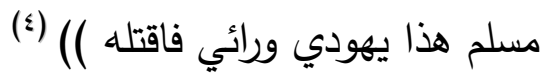

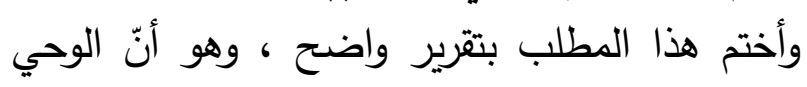
المنصوص عليه من الله تعالى ( في القرآن الكريم)

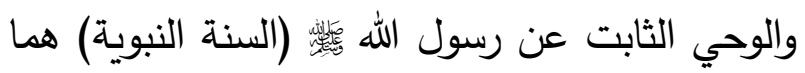
الوسيلة المضمونة والمباشرة في استشراف المستقبل

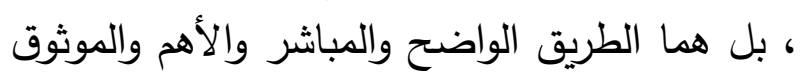

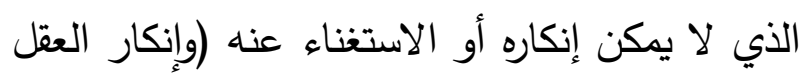

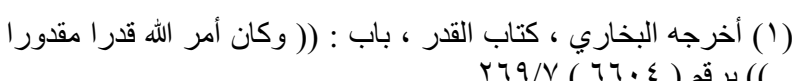

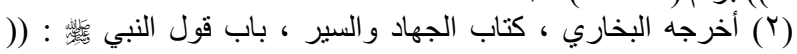

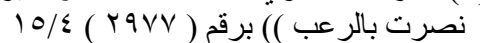

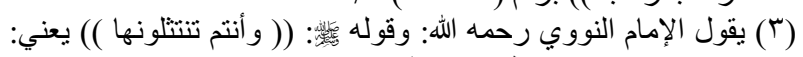

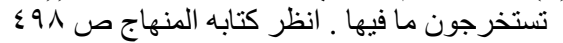

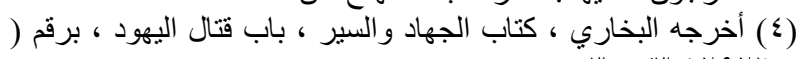

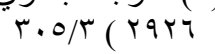

فإذا وقعت كانت علامة ودلالة على نبوته، وهي من

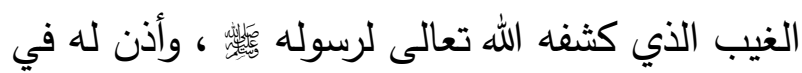

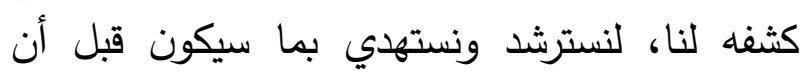

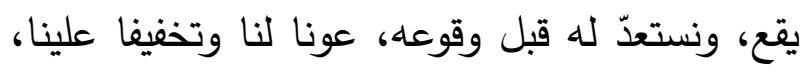
يقول حسن ضياء الدين عتر : ( والبشر مهما بلغوا

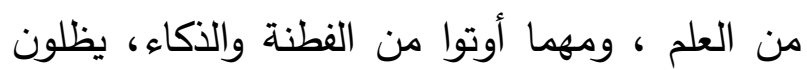

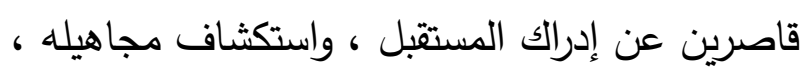
ولا يجرؤ عاقل على استصدار حكم قطعي بشأن الدان

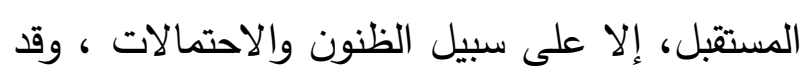

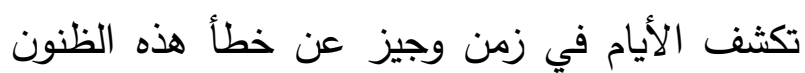

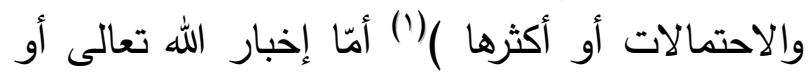

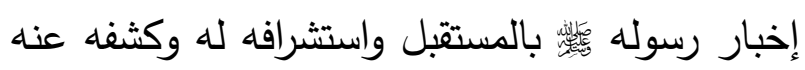
فهو وحي اطلعنا الله عليه . ولذلك كان التصيص على المستقبل بالوحي بوروده في القرآن والسنة الوسيلة الأولى الموثوقة ، والطريق التيقي

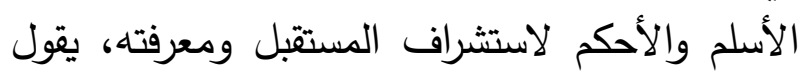

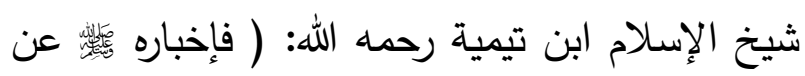
الأمور المستقبلية هو من باب العلم الخارق، كإخباره

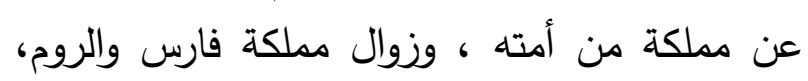

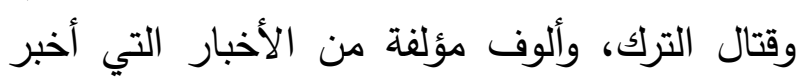
بها مذكورة بعضها في كتب دلائل النبوة، وسيرة

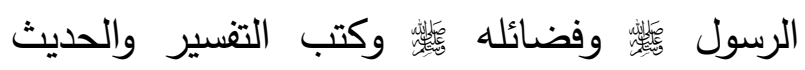

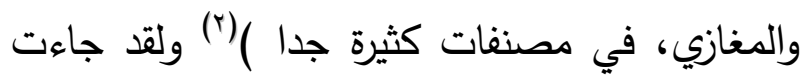
نصوص صريحة ومباشرة في كثف ستار المستقبل

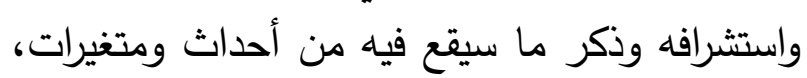

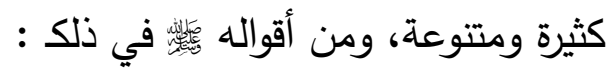

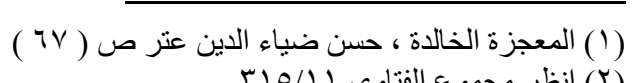


أولئك الذين يقومون بواجب الدعوة إلى الله تعالى وتجديدها، وتأصيل قضضاياها وخطواتها تأصيلاً

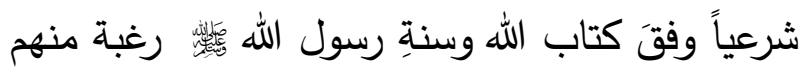
في: ( إحياء ما اندرس من العمل بالكتاب والسنة

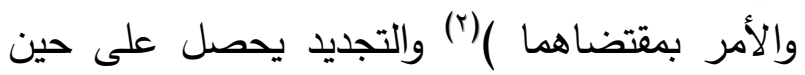
فترة وضعف في الأمة، فيسخّر الله لها من يجمع

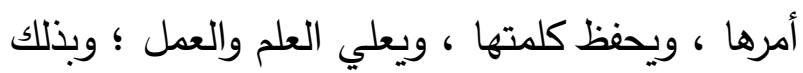

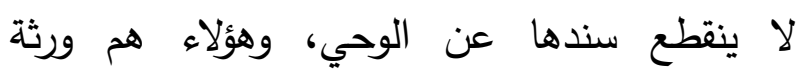
النبوة (r) ( وبمثل هؤلاء الأئمة والعلماء المجددين ، ومن يسير على دربهم من الفقهاء والدعاة الموثوقين ؛ ونظرهم

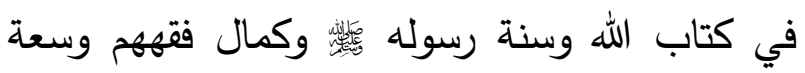

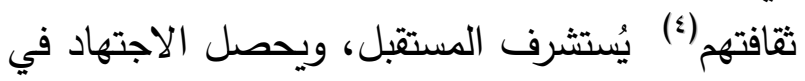
ما سيطرأ وما سيقع من أحداث، حيث وجد من تشدد في مسألة الاجتهاد؛ ووضعوا للمجتها شروطا تعجيزية حتى أغلقوه مطلقا، ومنهم من توسع فيه

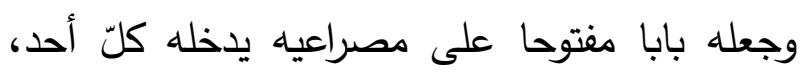
والخلاصة أنَّهـ أمر ضروريّ ، وباب مفتوح بحقه لمن

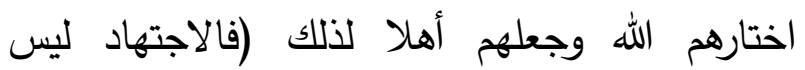
مفتوحا لكلّ أحد ، وليس مغلقا إلى الأبد؛ وهو ماضٍ

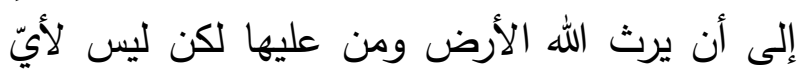

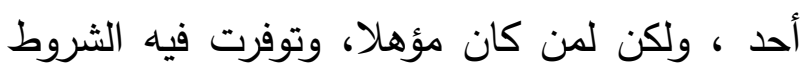

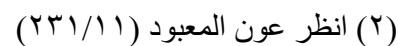

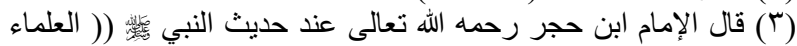

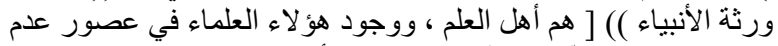

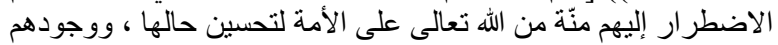

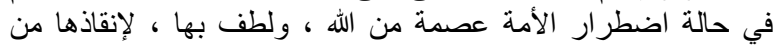
التهلكة ، ومساعدةً لها على حمل الألى على الرسالة الخاتمة ] انظر فتح الباري

(ع) الثقافة الواسعة والمتنوعة في مختلف المجالات العلمية والعملية

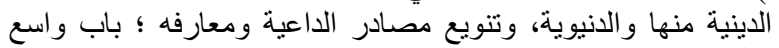

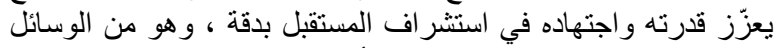

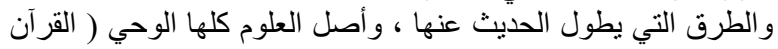

و السنة )

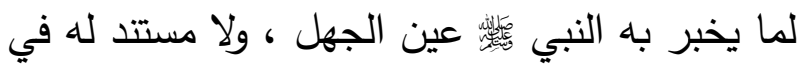

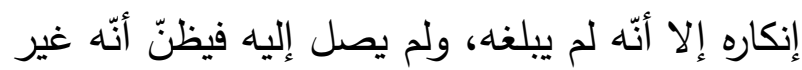

ثابت في نفسه ) (')

المطلب الثاني: الاجتهاد من أهل العلى العلم والكفاءة والتأهيل:

الاجتهاد ضرورة شرعيّة، وهو من لوازم التشريع التي

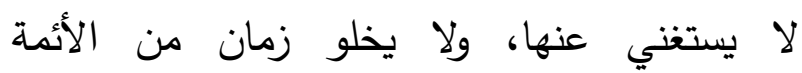
المجتهدين الذين يهدون الأمة ويوجهونها ، ويبيّنون

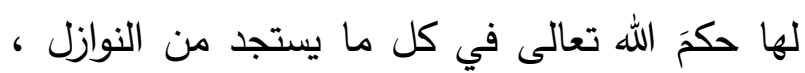
ويبذلون الؤسع والنظر ليواكبوا جميع الأحداث لهاث الطارئة في الدعوة إلى الله ، وخاصة في استشراف

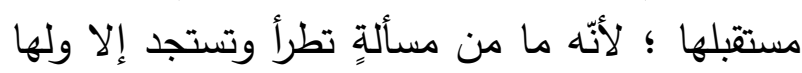

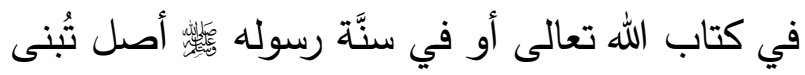
عليه قد يكون واضحا وقد لا لا يكون واضحا ومسؤولية المجتهد هي بذل الوسع للوصول للرابط

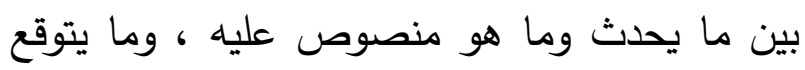

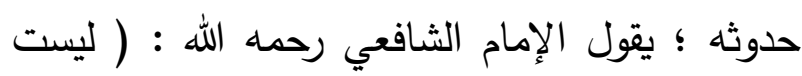

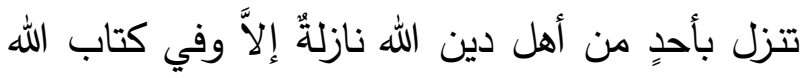

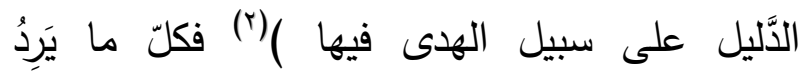

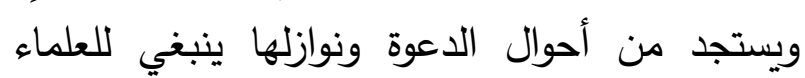

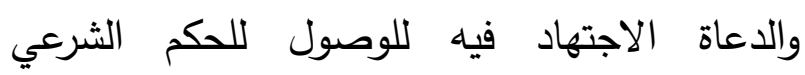

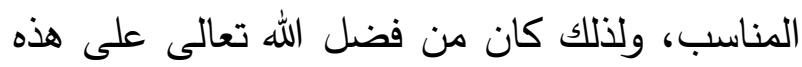

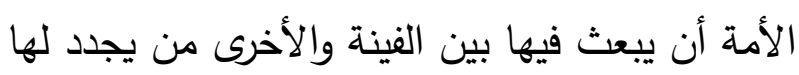

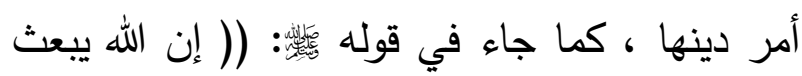

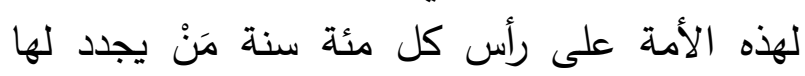

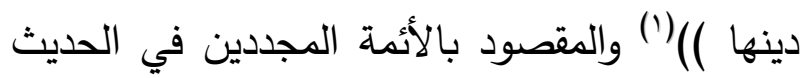

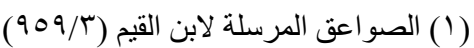

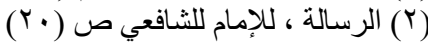

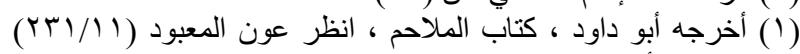

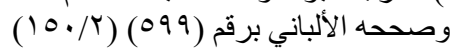


ضرورته وأنّه الأصل، حيث جاء في قراراته مانصّـه: (أن يكون الاجتهادُ جماعيًّا بصدوره عن مجمع فقهيّ

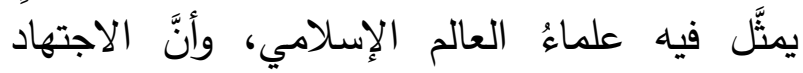
الجماعي هو ماكان عليه الأمر في عصور الخلفاء

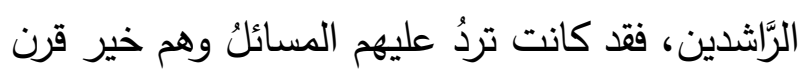

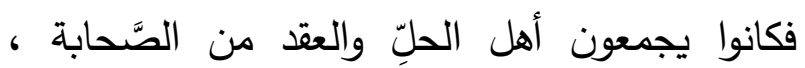

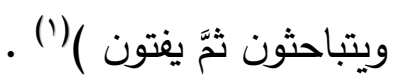
المطلب الثالث : مراعاة سنن الله الكونية واعتبارها: الكون كلّه قائم بأمر الله تعالى وفق نظام وترتيب دقيق؛ ليحصل الثبات والاستمرار في هذه الحياة فكل

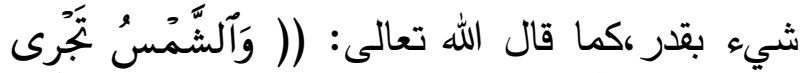

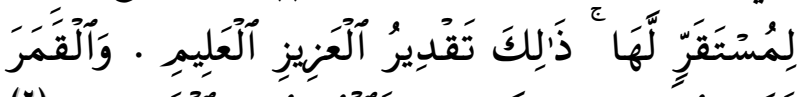

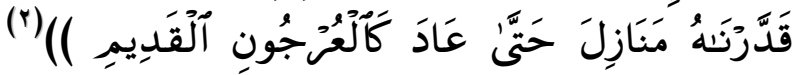
والسنن التي تحكم الكون والمخلوقات واحدة وثابتة ومقدّرة، وفق نظام دقيق ومنضبط، ومنهج رباني

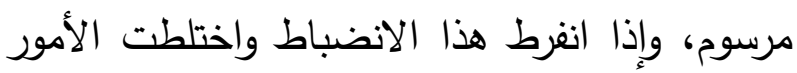

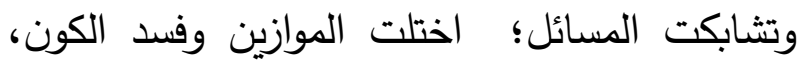
ولم يكن للوجود معنى، والدعوة الإسلامية والتي هي التئي

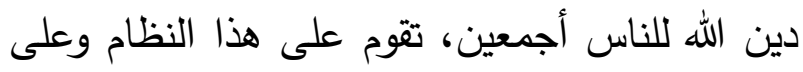
هذا الترتيب والتتاسق، ولذلك فلابد أن تكون خطوات

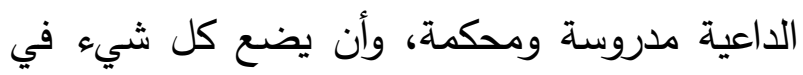
موضعه ، ولا يستعجل الثيء قبل أوانه (فقد يكون

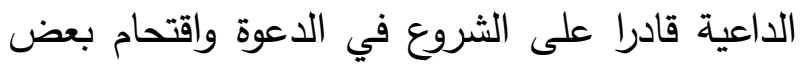
صعابها، ولكن الدعوة تحتاج إلى استمرارية وثبات

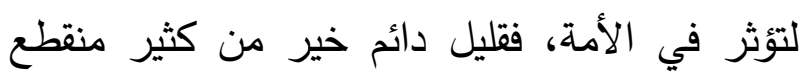
لاسيما في الدعوة)(') فالمطلوب من الداعية الناجح

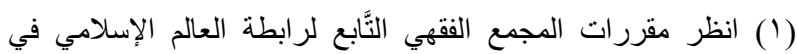

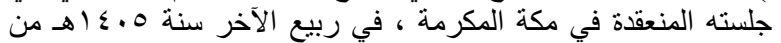

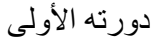

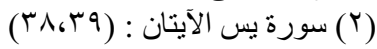

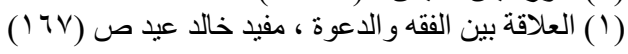

اللازمة)(') وهو هنا بنوعيه الفرديّ والجماعي وسيلة لاستشراف المستقبل.

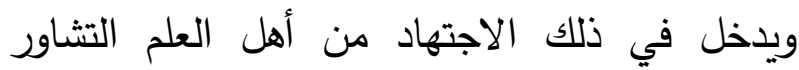
والتباحث وعقد اللقاءات والندوات والمؤتمرات وتحرير

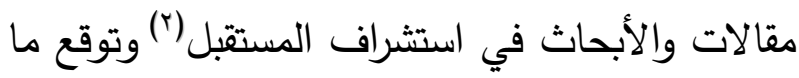
سيكون من أحداث ومتغيرات ، تحتاج الدعوة والدعاة

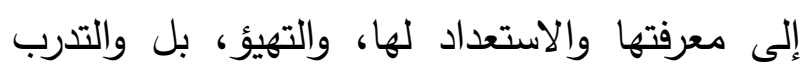

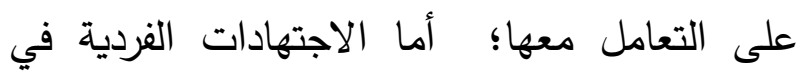
قضايا الدعوة المصيرية والنوازل المعقدة فضررها

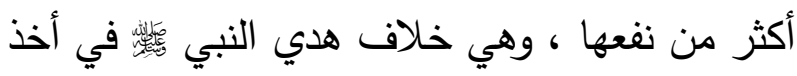

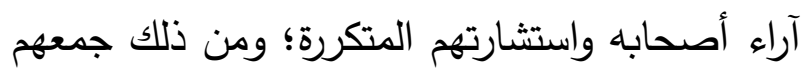

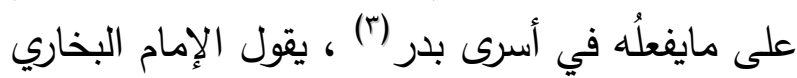

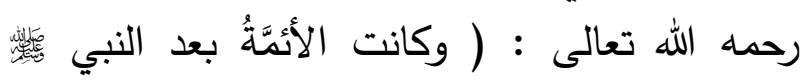

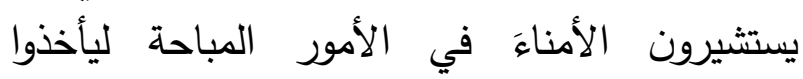

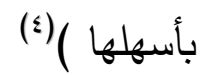
وعليه فمن الطرق المهمة لمعرفة المستقبل واستشرافه الاجتهاد سواء فيما كان فيه نص، أو فيما لم يكن

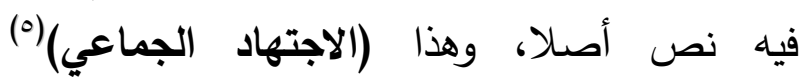
للوصول إلى معرفة بعض الحوادث والمتغيرات المستقبليّة؛ هو الذي ينبغي السعي إليه وتبنيه فهو أدق وأصوب، وقد أشار مجمع الفقه الإسلامي إلى الـى لإنى

( ( ) إعلام الموقعين عن رب العالمين ، لابن القيم (r/ • به) .

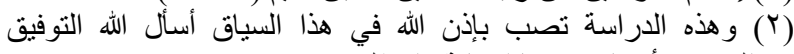

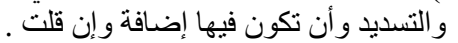

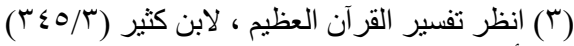

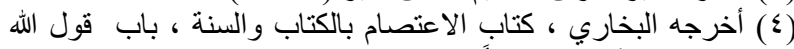

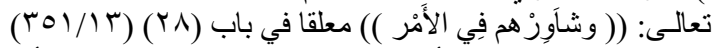

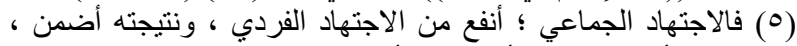

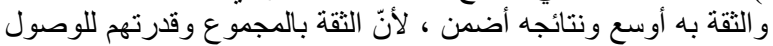

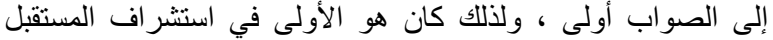

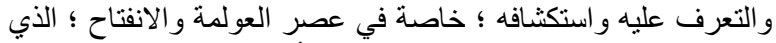

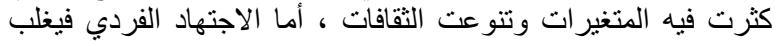

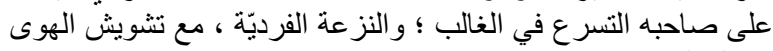
وحظوظ النفس فيه . 
الوحي، وبعض السنن أخصّ من بعض في الدلالة على المستقبل واستشرافه.

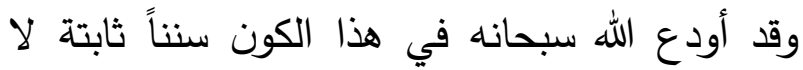

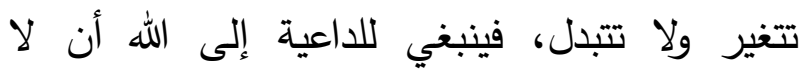
يتجاهلها بل يقف عندها ويتدبرها، ويتثقف في دراسة هذه السنن الكونية ؛ لتتبين له الحقائق والمعالم التي تكثف الطريق وتُعين على الصواب في دعوته ومع مدعويـ؛ وخاصة السنن الكونية المتعلقة بالأمم

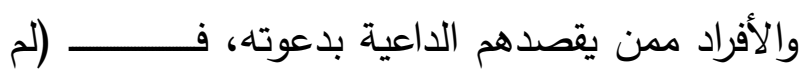
يُقَِّّر المُصنفون من المتقدمين والمتأخرين في شيء من علم الكتاب والسنة كما قصروا في بيان ما هدى مان

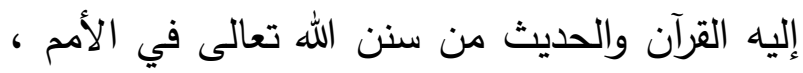
والجمع بين النصوص التي وردت في ذلك، والحث على الاعتبار بها، ولو عُنُوا بذلك بعض عنايتهم

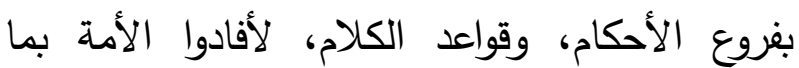
يحفظ دينها ودنياها ، وهو ما لا يغني فيه التوسع في دقائق مسائل النجاسة ، والطهارة والسَّلم والإجارة، فإن العلم بسنن الله تعالى في عباده لا يعلوه إلاّ العلم

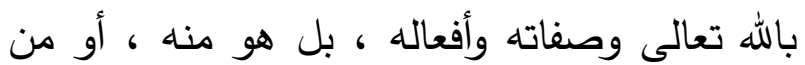

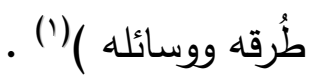

وسنكتفي في هذه العجالة بالتعريج على سنتين كونيتين تكشف لنا المستقبل ، وتعرفنا بما قد سيقع فيه وهي :

أولا :سنة الابتلاء: فالابتلاء هو مقصد من مقاصد

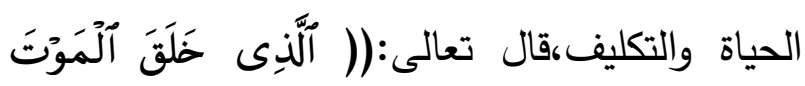

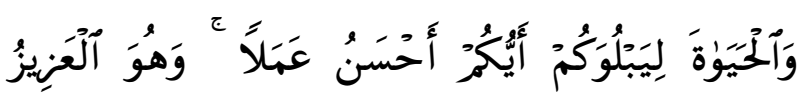

(1) من أقوال الثيخ محمد رشيد رضا، نقلا عن (سر تأخر العرب

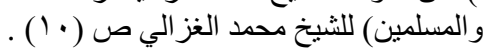

أن يعرف أين يضع قدمه والمطان المناسب لذلك ؟ وما هي خطواته القادمة التي تعينه على القيام بواجب الدعوة وتمكنه من عمارة الأرض ؟ وهذه السنن الكونية على ضربين، مادي واجتماعي (؟) والذي يهمنا في هذا الموضوع هو الجانب الاجتماعي في سنن الله وقوانينه الكونية والتي لا لاعول تتغير ولا تتبدل قال تعالى : (( سُنَّةَ اللَّهِ فِي الَّنِينَ

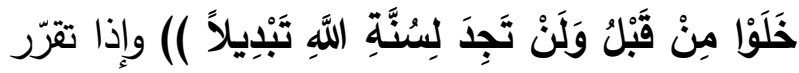
عدم تبدلها، جاءت إمكانية الاستفادة منها في استشراف المستقبل وماذا سيكون بناء على سنة الله الكونية الاجتماعية التي لا تتغير ولا تتبدل، ومن

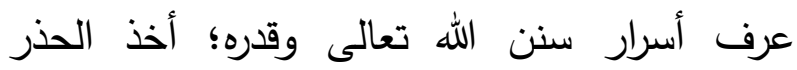
واتعظ، وأدرك ما وراء الواقع التاريخي من عوامل كامنة وأسباب ظاهرة ؛ من خلاله هذه المعرفة يمكن أن نتوقع ما سيكون استتادا إلى سنة الله التي لا تتبدل، والمقصود هنا الإشارة إلا أنّ هذه السنن ومعرفتها وسيلة مهمة ومباشرة في استكشاف المستقبل واستشرافه، لأنّ كثيرا مما سيقدره الله هو من سننه التي كشف عنها من خلال نصوص

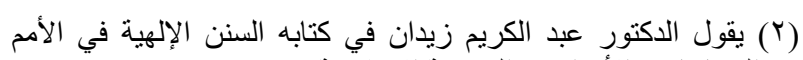

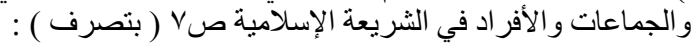

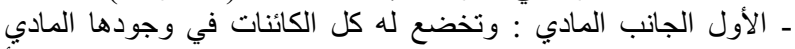

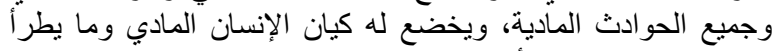

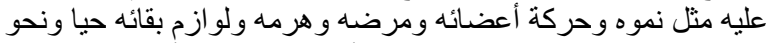
ذللك. و هذا الوجه لا يختلف في وجوده أهل أهل العلم بهذه الأمور المادية ولانه

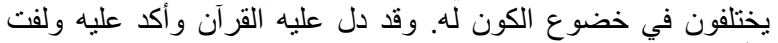
الأنظار إليه ليدل على ربوبية الله تعالى وتنمية الإيمان بالله واليوم

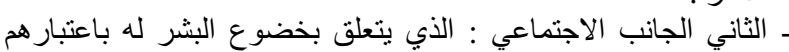

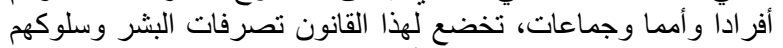

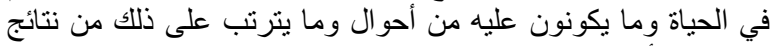

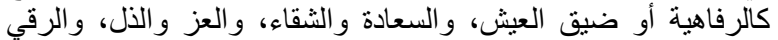

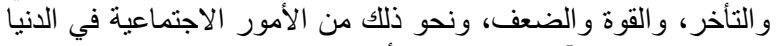

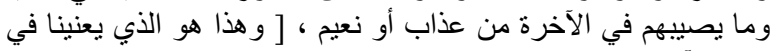

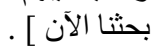


ثانيـا : سنة التـرج : فلقد خلق الله سبحانه وتعالى

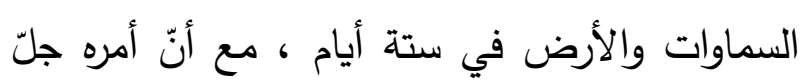

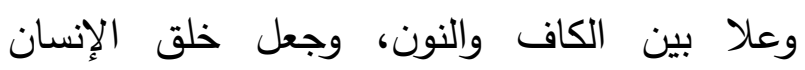
والحيوان متدرجا، عبر مراحل تصل به إلى الكمال والتمام ، وإلى الأجل المسمى الذي قدّره ، فلا ينبغي

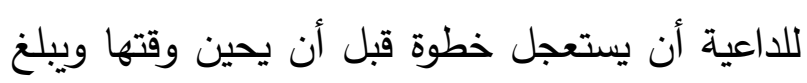

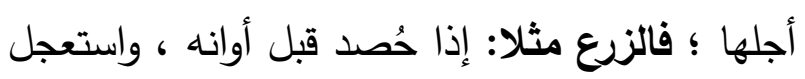
المزارع عليه فسد ولم يُنتفع به ، وإذا كان ظاهره

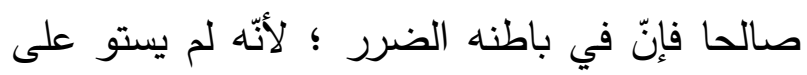

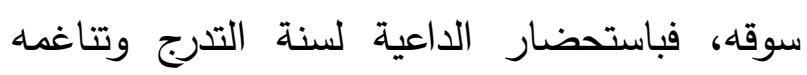
معها، فلا يستعجل، ويسير عبر مراحل وخطوات

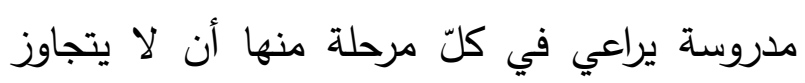

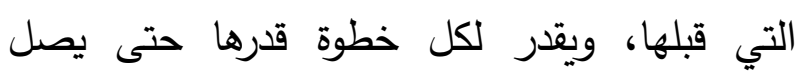
للخطوة التي بعدها، وبذلك ينال مبتغاه ويصل إلى فئل

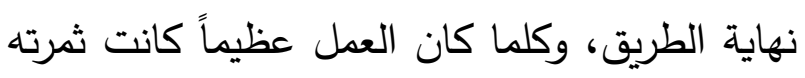
بطيئة وخطواته ومراحله شاقة ، ولكنّه سيقوم بنيانه

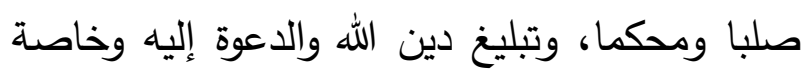

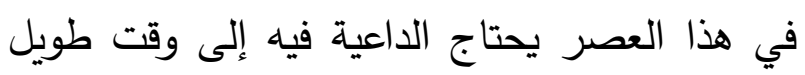
يتدرج فيه ومعه لتحقيق الهدف وقطع الطريق، بفقها لئه

$$
\text { وحسن استشرافه للمستقبل . }
$$

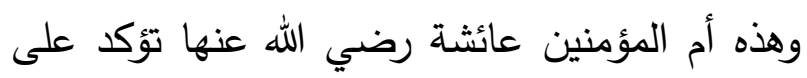

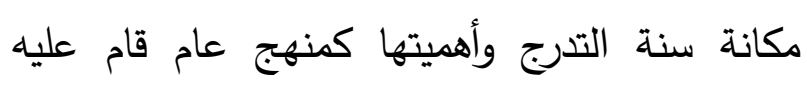

قال رسول الله

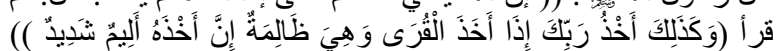

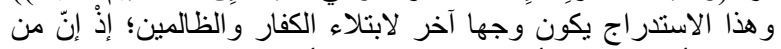

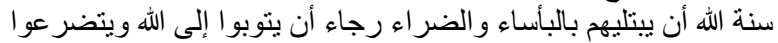

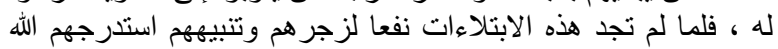

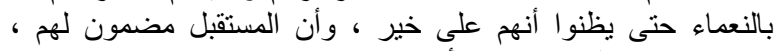
فيزدادوا إثما وطغيانا، ثم يفاجأهم العذاب و الهيلكا وانك.
آلَْفَُورُ ()(") فكل إنسان سيتعرض للبلاء حتى يتميز الناس وتظهر معادنهم، كما تقرر ذلك في الأحاديث

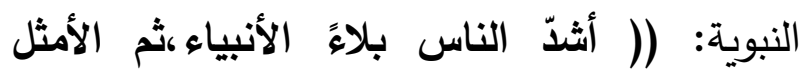

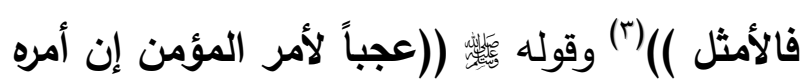

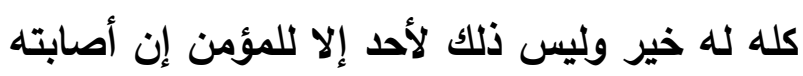

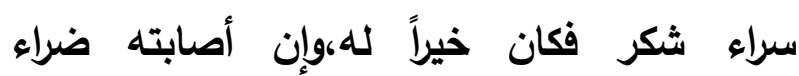
صبرفكان خير له)(|) وتندرج تحت سنة الابتلاء بعض السنن المتفرعة ومنها :

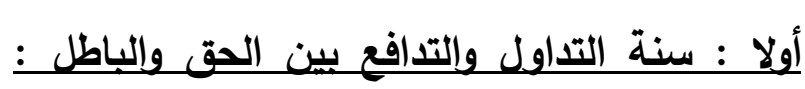
يعني أن الله تبارك وتعالى يداول أحوال الناس من

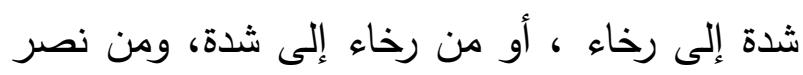

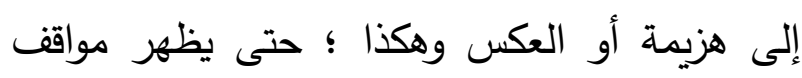
الناس ويكثف بواطن ما في صدورهم، وإن كانت العاقبة للمتقين وبلا شك .، وقد أراد الله أراد لهذه وان كله الحياة الدنيا أن تكون مسرحا للصراع والتدافع بين أهل الحق والباطل ، لأن تطبيق أحدهما يستلزم

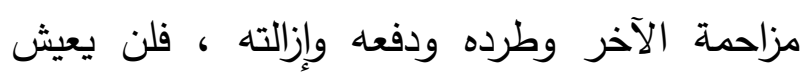
الحق والباطل في سلم ، بل الصراع بينهما محتدم ومستمر والغلبة في نهاية المطاف للحق وأهله ، كما أنّ هذا التدافع عاقبته للمؤمنين حميدة ، وعاقبته

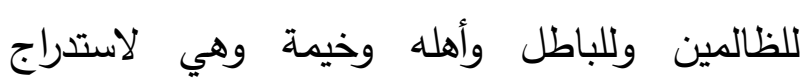

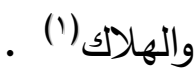

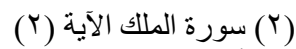

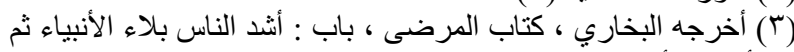

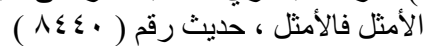

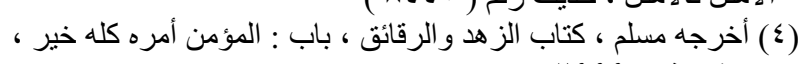

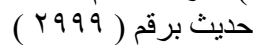

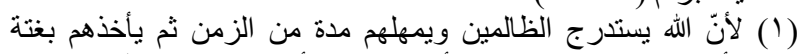
وفجأة دون سابق إنذار ، فعن أبي موسى الأشعري رضي الزي الله عنه قال: 
وقيمتها لمعرفة المستقبل واستشرافه ما جاء في السنة

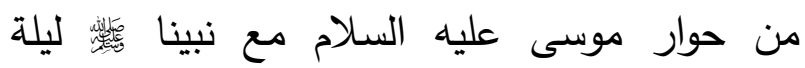
الإسراء والمعراج في شأن الصلاة أنه جرّب قومه فيها فلم يقدروا عليها وقصّروا فيها فكانت نصيحة

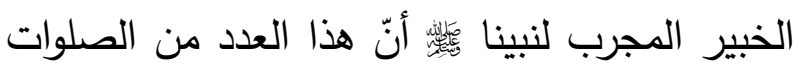
في اليوم لن يقدروا عليه، وأن يسأل ربه التخفيف: (إنّ أمتك لا تستطيع خمسين صلاة كل يوم ، وإني والله قد جرّبت الناس قبلك ، وعالجت بني إسرائيل أشدّ المعالجة ، فارجع إلى ربك فأسأله التخفيف لأمتك... )(") فالعاقل يردّ الأمر إلى أهل الخبرة والتجربة، وغيره يذيع الأمر ولا يرده قال تعالى:(( وَإِذَا

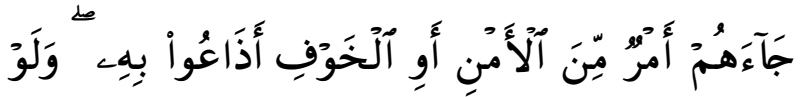

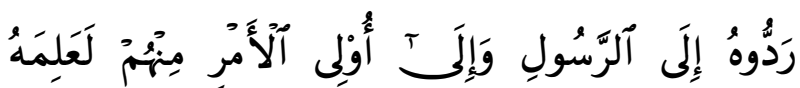

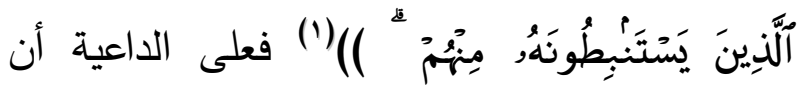
يحصّل هذه الخبرة بالتواصل مع العلماء والدعاة وأهل السابقة والخبرة، والحرص على الاستفادة منهم ومن جهودهم ؛ لينال ثقتهم، لأن ثقته بنفسه وخبرته لاتكفي بل لابذّ من توثيق غيره له من أهل العلم والدعوة المعروفين بسلامة المنهج ، ولذلك كان السلف الصالح لا يتصدر الواحد منهم إلا بعد الشهادة والإذن له؛ يقول الإمام مالك رحمه الله: ( ماء أفتيت حتى شهد لي سبعون أني أهل لذلك )(r) كما

\footnotetext{
ماسيحصل لهم ، وما قد يطر أ في مقتبل الأيام ، وكيف تتطور حالتهم المرضيّة .

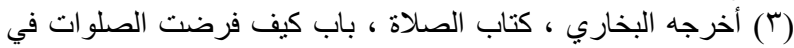

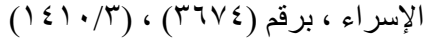

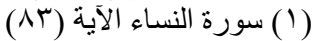

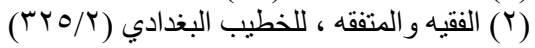

التثريع فتقول : (( إنما نزل أول ما نزل من القرآن سور من المفصل فيها ذكر الجنة والنار حتى إذا ثاب الناس إلى الإسلام نزل الحلال والحرام ، ولو نزل أول شيء لا تشربوا الخمر قالوا : لا ندع الخمر

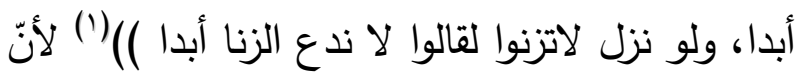
كل مرحلة تكشف التي بعدها، وتمهد لها ، ليستشرف الداعية الخطوة اللاحقة التي يقدم عليها ، وفي السنة النبوية؛؛ جاء التدرج واضحا جدا عند استخدام جبريل عليه السلام لله عند سؤالاته المشهورة في أركان الإيمان والإسلام والإحسان وغيرها من مهمات الدين وأصوله في الحديث المشهور (r) حيث تظهر تلك الدقة المتناهية في ترتيب الأسئلة من السائل إلى المسؤول والتدرج فيها، والبداية بالأهم ثم المهم ترتيبا علميا منطقيا.

\section{المطلب الرلبع : التحربة والخبرة الاعويـة الطوبلة :} التجربة هي: اختيار عمل لمعرفة نتائجه وإدراك ثراته،والرجل المجرب هو الذي يعرف الأمور

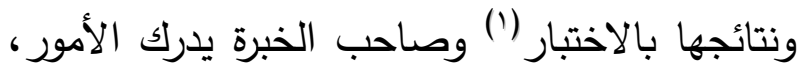

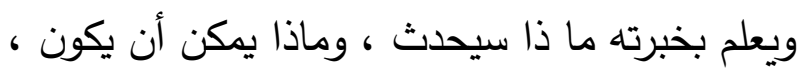
وما هو الأمر الذي سيترتب على هذا الواقع في مستقبل الأيام(r) ومما يدل على مكانة التجربة

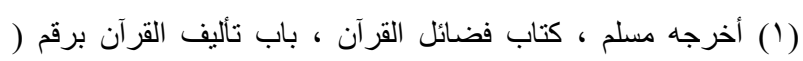
. ( I Y r/7 ) ( ₹997

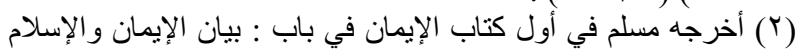

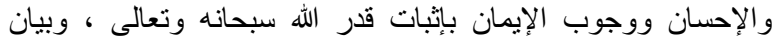

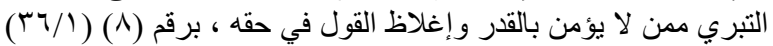

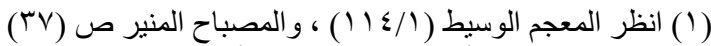

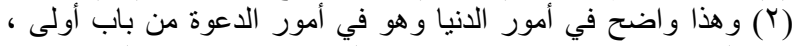

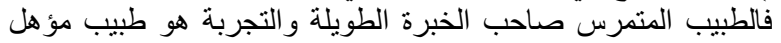
وقادر على علاج مرضاه ؛ لأنّ يستشرف مستقبل حالتهم ، بعلم بالخبرة 
مبينا مكانة الرؤيا وأهميتها : ( فإنَّ العبد إذا نفذ فيها،وكمل اطلاعه جاء بالعجائب ، وقد شاهذنا نحن وغيرنا من ذلك أمورًا عجيبة، يحكم فيها المعبِّر

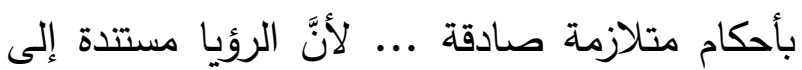
الوحي المنامي ، وهي جزء من أجزاء النبوة ، ولهذا كلما كان الرائي أصدقَ وأبرَّ وأعلم كان تعبيره أصحَّ، بخلاف الكاهن والمنجّم وأضرابهما ممن هم مدد من إخوانهم الشياطين،فإنَّ صناعتهم لا تصحُّ من صادق

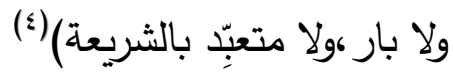
فالرؤيا فيها من المنافع الكثير فهي وسيلة مباشرة في استشراف المستقبل واستكثافه والتعرف عليه، وهي من إكرام الله لعبيده؛ لأنّها (قد تكون منذرة من قبل الله تعالى لاتسرّ رائيها، وإنما يريها الله تعالى للمؤمن رفقا به ورحمة ليستعدّ لنزول البلاء قبل وقوعه)(') يقول في أبجد العلوم:( ومنفعتُه البشرى بما يردِ على

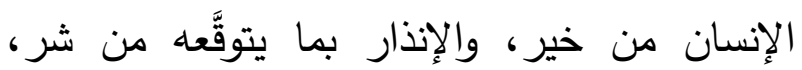

والاطلاع على الحوادث في العالَم قبل وقوعها) (r) فالنبي الوحي عليه صباح مساء، وهي طرق ووسائل مباشرة وموثوقة في استشراف المستقبل؛ إلا أنّه كان بعد صلاة الفجر يلتقت إلى الصحابة فيسألهج: من منكم رأى رؤيا البارحة ؟ وكان في أوقات الحرج يسألهم: هل رأى أحد منكم رؤيا؟ لأنّ الرؤيا الصالحة هي

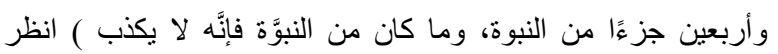

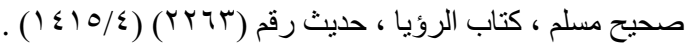

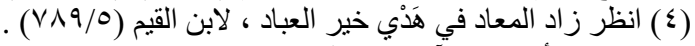

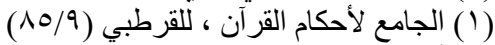

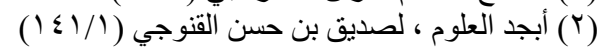

أنّه يستطيع تحصيل هذه الخبرة الدعويّة بالممارسة

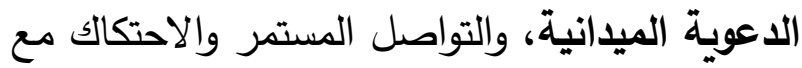
المدعوين وتلمس احتياجاتهم ومعرفة طبيعة معاناتهم، فالداعية الفقيه الذي يرغب التبصّر في استشراف مستقبل دعوته ومدعويه ينبغي أن لا لانيل ينفصل عن محيطهم، وألا يزهد في الاحتكاك بهم للوقوف على حقيقة حالهم؛ وذلك من خلال النزول إلى ميادين الدعوة، وعدم اكتفائه بالوقوف على على أبراج

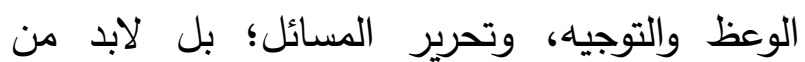

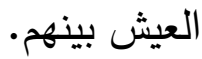
المطلب الخامس: الرؤيا الصادقة الصالحة : والرؤيا جمع مفرده رؤية ، وهي كل مايرى في المنام

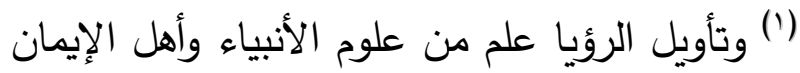
( وحسبك بما أخبر الله من ذلك عن يوسف - عليه

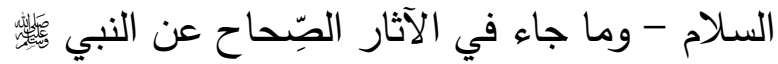

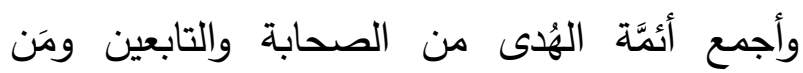

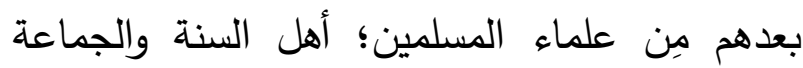

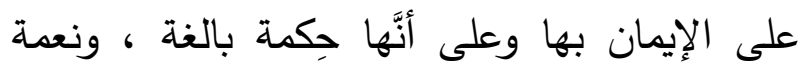

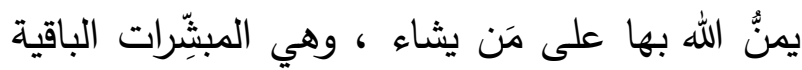

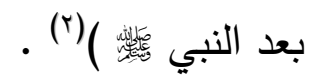
ومن دلالات أهمية الرؤيا الصالحة ومكانتها أنَّها أول هذا الدّين وآخره(ז) ، يقول الإمام ابن القيم رحمه الله لهال

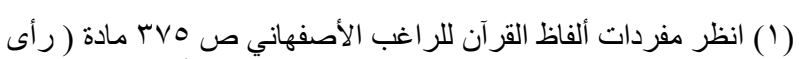

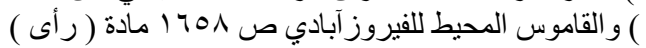

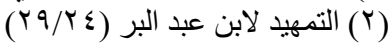

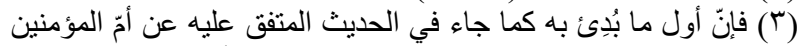

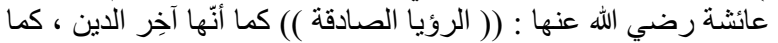

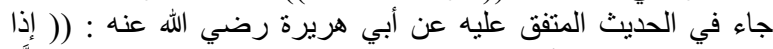

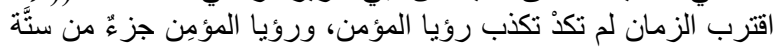


في المستقبل بعد خروجهم، وجاء في تعبيره لرؤيا الملك المتكررة عليه وضع تصور لخطة مستقبلية ناضجة، وتخطيط محكم للتعامل مع المستقبل. وتتأكد الاستفادة(ז) من هذه الوسيلة في آخر الزمان؛ أي في عصورنا اليوم كما قال ئسئ: (إذا اقترب الزمان لم تكد رؤيا المؤمن تكذب وأصدقهم رؤيا أصدقهم حديثا )(r) ويتأكد مع ذلك معرفة الأحكام الشرعيّة المتعلقة بالرؤيا، وضوابط تعبيرها ، والمؤهل للتصدر لها(') فبعد انقطاع الوحي؛ الذي هو هوليا، المصدر الموثوق لكثف المستقبل والإخبار به ؛ لم يبق لنا من المبشرات والنبوة إلا الرؤيا الصالحة، يسترشد بها، ويستهدي بهديها، ويستشرف بها المستقبل، كما

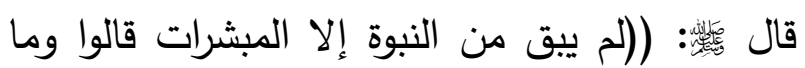
المبشرات؟ قال الرؤيا الصالحة)(ب) وبالجملة(r) فعلى الداعية أن يتحرى في الرؤى وفي تعبيرها، ويقصد الخبير الصادق في ذلك، حتى

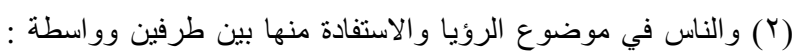

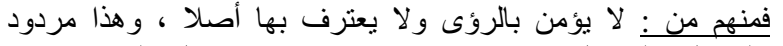

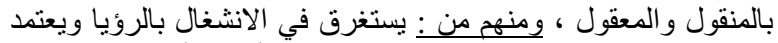

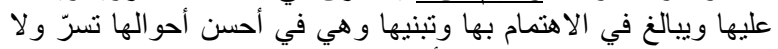

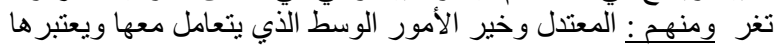

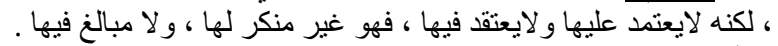

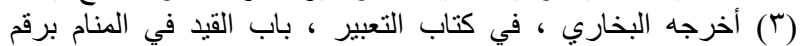
$(r \cdot r / \varepsilon)(V \cdot 1 V)$

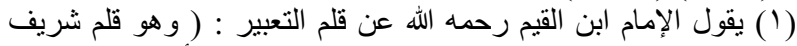

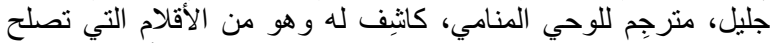

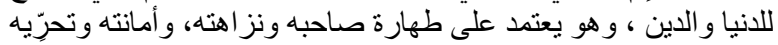

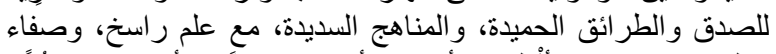

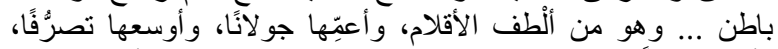
و أنثدها تثبنًا بسائر الموجودات ) الطظر كتابه : التبيان في أقسام القرآنا

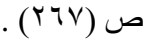
(r) أخرجه البخاري ، في كتاب التعبير ، باب المبشر ات برقم ( • (799) $(\varepsilon \cdot r / l \varepsilon)$

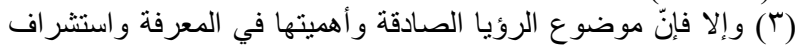

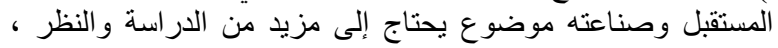

أحد الوسائل والنوافذ إلى قراءة المستقبل، وهي وسيلة مهمة يستأنس بها في ذلك ولا يعتمد عليها، وقد جاءت النصوص بأن الرؤيا جزء من النبوة وأنها ما تبقى من مبشرات النبوة التى أراد الله بها أن يعرف

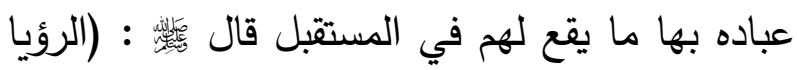
الحسنة من الرجل الصالح جزء من ستة وأربعين جزءا من النبوة )(r) ويكفي للتنبيه على أهميتها وتأكيد صلتها بالوحي وكونها ما تبقى من مبشرات النبوة أنّ النبي مرضه الذي انتقل بعده إلى الرفيق الأعلى -بأبي هو وأمي - والناس صفوف خلف أبي بكر رضي الله عنه فقال: (( أيها الناس إنه لم يبق من مبشرات النبوة إلا الرؤيا الصالحة يراها المسلم أو ترى له )(1)" والرؤيا الصادقة هي إطلاع الإنسان على القضاء قبل أن يتحقّق فيصبح قدراً ، وجاءت رؤيا نبي الله يوسف عليه السلام في صباه كاشفة لمجموعة من الرؤى التي كثفت عن غيب مستقبلي، أدّى إلى ما سيحدث له في المستقبل، مما أثّر على أبيه في طريقة تعامله معهه والثفقة عليه، وما أدّى إلى تآمر إخوته عليه، فكان ذلك كله مقدّمة لسلسلة من الأحداث؛ انتهت إلى تحقق الرؤيا وحصول ماكان يتوقع من الملك والتمكين، وكثف عليه السلام لصاحبي السجن في تعبير رؤاهم ما سيقدمون عليه

(r) أخرجه البخارى ، كتاب النعبير ، باب القيد في المنام ، برقم

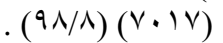

(1) أخرجه مسلم وغيره من طريق إبر اهيم بن عبد الله بن معبد عن أبيه

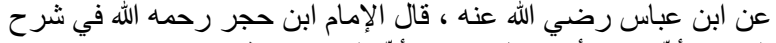

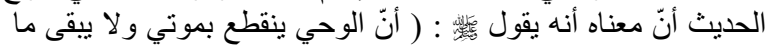

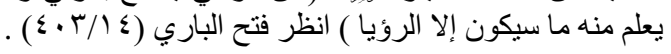


الميدانية ، والرؤيا الصالحة يراها الداعية أو ترى له ، فإنّ الأسباب والوسائل المعنوية لاستشراف المستقبل ومعرفته والكشف عنه ينبغي أن تكون حاضرة، وعلى ألى رأس تلك الوسائل والأسباب المعنويـة توفيق الله تعالى ولى بصدق اللجوء إليه، وإخلاص الدعاء لله، وهذه المعاني السامية لا تنافي الأخذ بالأسباب والوسائل كما يظنه البعض، بل هي قبل الأسباب، وبعد الأسباب ، ومن أقوى الأسباب ، وعلى رأسها الدعاء

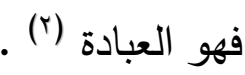
فمما يُعين الداعية إلى الله على معرفة المستقبل، ويساعده في استشرافه توفيق الله تعالى له وتسديده في ذلك؛ وذلك بحسن نيته وتصحيحها ، وإخلاص وله مقصده ، وكثرة دعائه وطلبه العون والتوفيق من الله، وذلك أنّ الدعاء هو طلب، والطلب متوجه للمستقبل، فالداعي يتلمس المستقبل ويقصده، والمستقبل المغيب هو إما نفع متوقع أو ضرّ متوقع ( والدعاء من أقوى الأسباب في جلب المنافع ، ودفع المضار)(') كما أنّ الدعاء أصل مهم لتحصيل الصواب ونوال السداد، وتسهيل القادم، وإدارة المستقبل(r) ولذلك كان

(Y) قال الإمام ابن القيم:( فاعلم أن نفاة الأسباب لا بستقيم لهم توكل ألبتة.

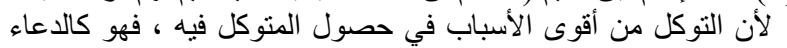

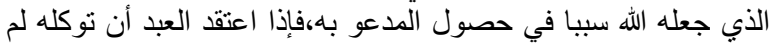

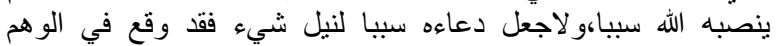

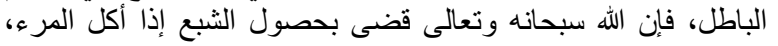

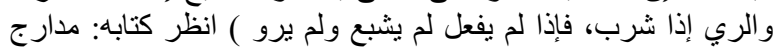

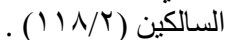

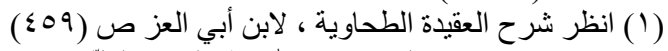

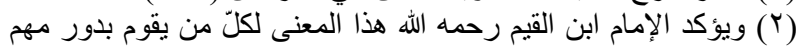

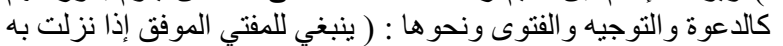

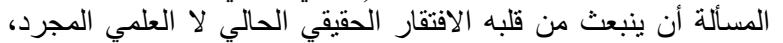

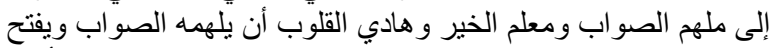

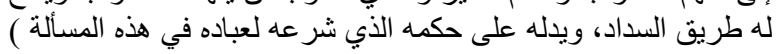

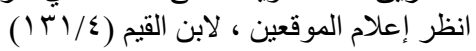

يستثيد من هذه الوسيلة في استشراف المستقبل؛ لأنها

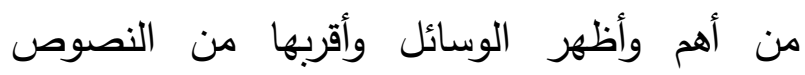

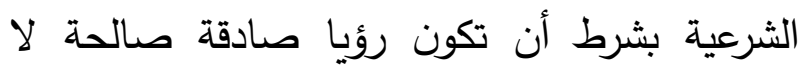

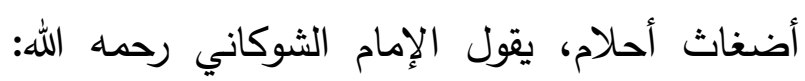

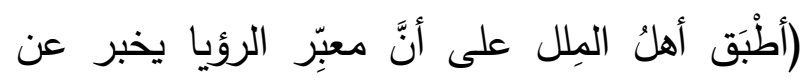
أمور مستقبلة، ويكون صادقًا فيها ) (s) كما أنّ عليه

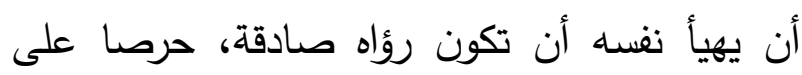

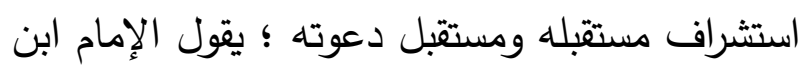
القيم: ( ومن أراد أن تصدق رؤياه فليتحر الصدق دوان الإمان وأكل الحلال والمحافظة على الأوامر والنواهي، ولينم

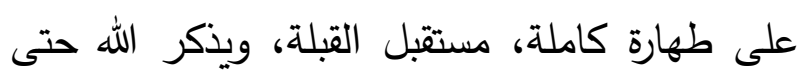
تغلبه عينه، فإن رؤياه لا تكذب البتة، وأصدق الرؤيا

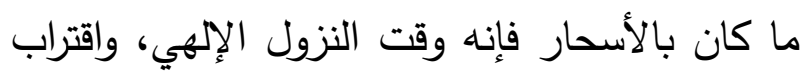
الرحمة والمغنرة، وسكون الثياطين، وعكسه رؤيا العتمة عند انتثار الشياطين والأرواح الشيطانية)(').

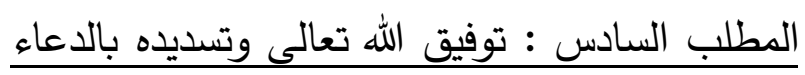
والاستخارة والتوكل عليه واللجوء إليه : وفي سياق الكلام عن توفيق الله تعالى وتسديده، وكثفه للاعية مستقبل أيامه وما سيقع من أحداث ومتغيرات، فالتأكيد هنا على أهمية الأخذ بالوسائل

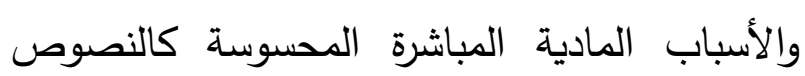

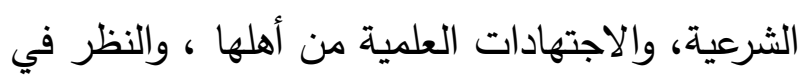
السنن الكونية والاعتبار بها، والتجربة والخبرة

ولعلّ في العلاقة بينها وبيّن النبوة أنّ في كل منهما أسرارا و علوما من

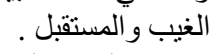
( ) فتح القدير الجامع بين فني الرواية والدراية من علم التفسير

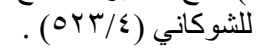

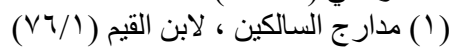


أمري، أو قال في عاجل أمري وآجله فاصرفه عني واصرفني عنه واقدر لي الخير حيث كان ثم رضني باه ويسمي حاجته )(') ففي الدعاء ( وعاقبة أمري ) والعاقبة هي المستقبل، فدعاء الاستخارة مسلك شرعي، وطريق سليم، ووسيلة مشروعة، تؤكد أنّ في الحلال ما يُغني عن الحرام، فقد حرم الله تعالى على ولى لئى

عباده الاستقسام بالأزلام وعوضهم بالاستخارة (r) . الخاتمة وأهم النتائج والتوصيات:

وفي الختام أحمد الله تعالى على التمام وأسأله حسن

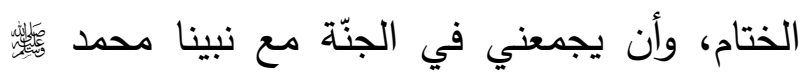
وصحبه الكرام، ومن سار على هديه واتبع سنته من الأنام، كما أسأله أن يجيب دعوتي، ويستر عورتي، ويغفر زلتي.

وأخيراً فإني أحمد الله عز وجل الذي منّ عليّ بإتمام

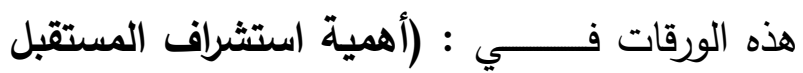
والتخطيط لله وحاجة الاعوة والااعية إليه وأهم وسائل وطرق ذلكـ ) وتأصيل هذا الموضوع، وإبراز ما فيه من المعاني والمعالم والدلالات، وأهم التوصيات والنتائج التي أختم بها هذه الجها

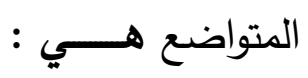

1- يوصي الباحث نفسه وطلاب العلم وجميع المسلمين بتقوى الله عزو جل ، ويدعوهم إلى التمسك

(1) أخرج البخاري ، كتاب الدعوات ، باب الدعاء عند الاستخارة برقم

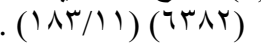

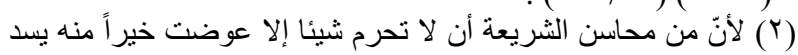

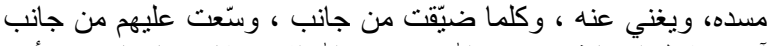

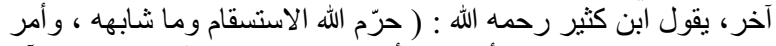

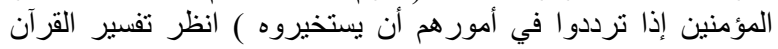

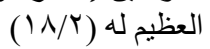

من دعائه جبرائيل وميكائيل وإسرافيل فاطر السموات والأرض عالم الغيب والثهادة أنت تحكم بين عبادك فيما كانوا فيه يختلفون، اهدني لما اختلف فيه من الحق بإذنك؛ إنّلك تهدي من تثاء إلى صراط مستقيم )( ) ويتفرع عن الدعاء من وسائل استشراف المستقبل ومعرفته ( الاستخارة )(ץ) لأنّها تتعلق بالمستقبل؛ والداعية بحكم مسؤولياته ومايتصدر لله من مهام وتبعات، كما أنّه كغيره من الناس، قد يعتريه القلق، وتتداخل عنده الرؤى والاجتهادات، فيقع في الخوف من المستقبل المجهول الذي يترقبه، ويتردد مرات ومرات هل يقدم على هذا الفعل ؟ أم على غيره ؟ وهل الأولى الإقدام أصلا عليه ؟ أم الإحجام عنه ؟ فشرع الله له في مثل هذه الحالات وعند هذه المواقف الإن الاستخارة، لتكثف لله بصيصا من المستقبل الذي ينتظره، وتساعده على الاطمئنان بما سيختاره الله تعالى له، ويقدم عليه، فعن جابر فئئ، قال:كان يعلمنا الاستخارة في الأمور كلها يقول : (( إذا همّ أحدكم بالأمر فليركع ركعتين من غير الفريضة ثم يقول اللهح إني أستخيرك بعلمك وأستقدرك بقدرتك وأسألك من فضلك العظيم، فإنك تقدر ولا أقدر وتعلم ولا أعلم وأنت علاّم الغيوب ، اللهم إن كنت تعلم أن هذا الأمر خير لي في ديني ومعاشي وعاقبة أمري ، أو قال في عاجل أمري وآجله فاقدره لي ، وإن كنت تعلم أن هذا الأمر شر لي في ديني ومعاشي وعاقبة

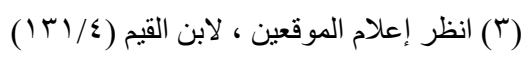


وبغير العلم الشرعي الأصيل المعتمد على الكتاب والسنة، فلامعنى للدعوة بل إنّ الخوض في غمارها يترتب عليه من الآثار الوخيمة مالا تحمد عقباه، وتقصير الداعية في العلم والتعلم نذير خطر يهدده

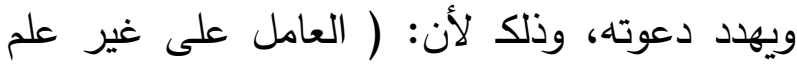
كالسالك على غير طريق والعامل على غير علم

$$
\text { يفسد أكثر مما يصلح ) (') }
$$

r- يوصي الباحث نفسه وإخوانه الباحثين، والجامعات، ومراكز البحث العلمي، والمهتمين بالدراسة والتأصيل، الاهتمام بـ بالفقه في الدين

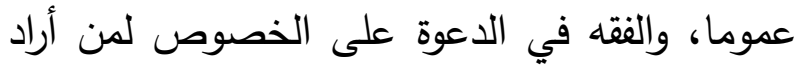

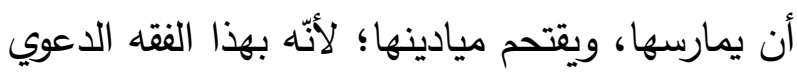
من خلال النصوص الثرعية، والتجارب الثخصيّة، والسنن الكونيّة، يحقق البصيرة في الدعوة المطلوبة

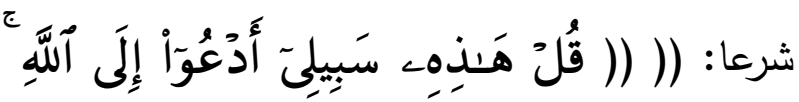

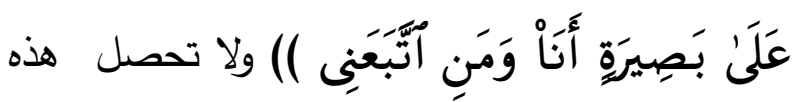
البصيرة المأمور بها والتي هي علامة الإتباع إلا بالعلم والفقه في الدين. ع- يوصي الباحث نفسه وجميع العاملين في مجال الدعوة إلى الله؛ الاهتمام والتفقه في المستقبل ودراساته لأنّ المستقبل هو الحياة القادمة كلها ، وهو الوعد القريب إن شاء الله بالنصر والتمكين، ولكن العناية والاهتمام بهذا الفقه المستقبلي والدراسات الاستشرافيّة ينبغي أن يكون باعتدال، وأن يقدر

(1) مفتاح دار السعادة ، لابن القيم (1/ (1 )
بدين الله، والقبض على دينهم وخاصة في هذه الأيام فإنّ القابض على دينه كالقابض على الجمر، ومن اتقى الله والتزم بأوامره ونواهيه؛ فقهاه الله في الدين ووفقه لكلّ خير، وأعانه على استشراف المستقبل ومعرفته، فالعلم من الله جلّ وعلا: (( قالوا سبحانك لاعلم لنا إلا ما علمتنا إنك أنت العليم (الحكيم)) وأصل ذلك كله تحقيق الإيمان في القلوب، ومعرفة أن الله تعالى استأثر بمعرفة الغيب فلم يطلع عليه

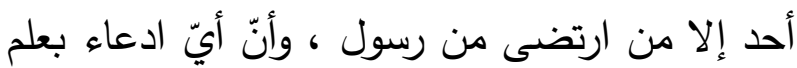

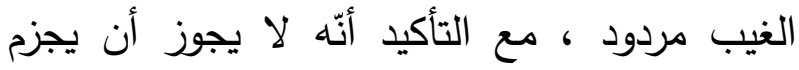

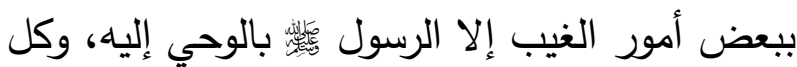

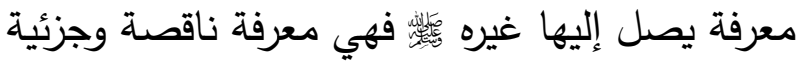

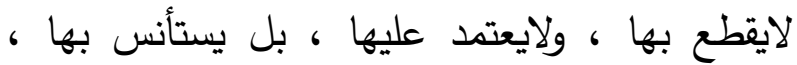
ويؤكد الباحث أنّ من كمال الإيمان وتحقيقه محاربة السحر والثعوذة والكهانة والعرافة وكلّ ما يفضي إلى لى

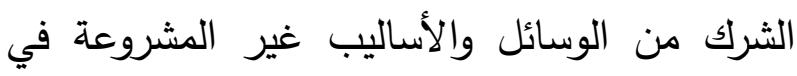
استشراف المستقبل ومعرفته واستكثافه . r- يوصي الباحث نفسه والباحثين ، والدعاة العاملين بزيادة الاهتمام والعناية بهذين المصدرين الجليلين (الكتاب والسنة) والردّ إليهما في كلّ صغيرة وكبيرة، ليفتح الله عليه، فعلمهما لا يتتاهى ولا تتقضي عجائبه، ولا ينقص مع كثرة الأخذ، ففيهما الكفاية، وبخوض غمارهما ، يقف الداعية بإذن الله على ما يصلح لله دنياه وآخرته، وتقتح عليه كنوز العلم والمعرفة والمستقبل ؛ ولا أدلّ على ذلك من تلك المعالم والمعاني التي ظهر في طيات هذه الدراسة ، 
نشر الإسلام وتمكينه، ونصرة المسلمين وعزّتهم، سائسهم ودليلهم الذي يسترشدون باه في ذلك هو الوحي، والمحجة البيضاء، وليثقوا بالله تعالى، ويطمئنوا بما لاشكّ فيه ؛ أنّ الأمر لله من قبل ومن بعد، وأنه في نهاية المطاف ستكون العاقبة للمتقين، والمستقبل لهذا الدين . فهرس المصادر والمراجع: بعد القرآن الكريم، مرتبة على حروف الهجاء، على النجو التالــي: - أن الت 1- أبجد العلوم : لصديق بن حسن القنوجي، دار الكتب العلمية ، بيروت 9V^ r - أساليب الاعوة الإسلامية المعاصرة : لحمد بن

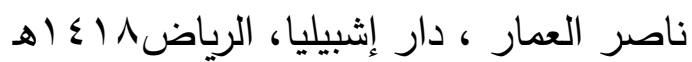

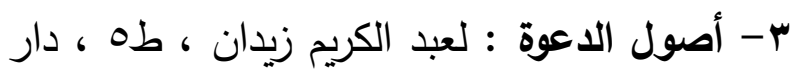

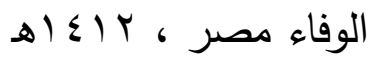
ع - أضواء البيان في إيضاح القرآن بالقرآن: لمحمد الأمين الشنقيطي، عالم الكتب، بيروت بدون ه- الاعتصام : للشاطبي، دار المعرفة، بيروت ه) $\varepsilon$ ج- إعلام الموقعين عن ربّ العالمين: لابن القيم ، طץ ، دار الفكر ، بيروت Vq V- إغاثة اللهفان من مصايد الثيطان: لابن القيم،

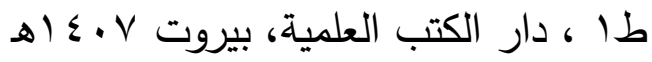

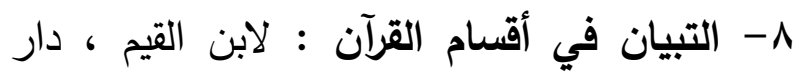

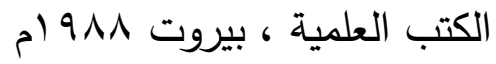
9- تحفة الأحوذي: للمباركفوري ، دار الكتب العلمية بيروت بدون
بقدره وأن لا يحصل الاندفاع والمبالغة في هذه الدراسات وهذا الاستشراف كما هو في الغرب، الذي لا يملك في ثقافته الأدوات والوسائل الموثوقة لاستشراف المستقبل واستكثافه، أما في الثقافة الإسلامية؛ فلقد اهتمت نصوص الوحي به، وبقدر معلوم يدفع كل واحد منّا إلى استشراف مستقبله، والتخطيط لحياته ؛ ليكون ممتدا بحياته في الدنيا إلى

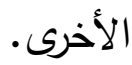

0- يوصي الباحث نفسه وجميع المهتمين بالدراسات الدعويّة ؛ أن يدركوا أهمية الآيات القرآنية ونصوص السنة النبوية ودراستها عموما، وما يخص المستقبل واستشرافه خصوصا، لأنّه أصبح اليوم ضرورة شرعية وحياتية، بل هو قبل ذلك وبعده حاجة فطرية، وسنة كونية لا يستغني عنه الجميع ، ومضامين هذا البحث كلها دالة على ذلك، وهدي الرسول بالمستقبل واستشرافه والتشمير والتخطيط له كلّها تدفع لذلك ؛ رغم أنّه وغيره تأكيد على أتباعه من الدعاة إلى الله أن يقتدوا به، وأن لا يقفوا مكتوفي الأيدي - موقفا سلبيا - من المستقبل ومتغيراته وأحداثة التي ستحل بدارهم (وكلّ

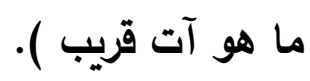
צ- يوصي الباحث نفسه وجميع المهتمين بالعلم والدعوة الاجتماع على كلمة سواء على مائدة القرآن الكريم والسنة النبوية المطهرة على صاحبها أفضل الصلاة وأتمّ والسلام، للتشاور والتدارس وتبادل الخبرات حول واقع الدعوة ومستقبلها ، وكل ما يهم 
r r - السنن الإلهية في الأمم والجماعات والأفراد في الثريعة الإسلامية صرف ) الاكتور عبد الكريم زيدان في بr - سنن الترمذي : للإمام أبي عيسى محمد بن

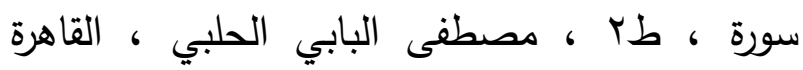
ه ؛ צ- سنن الدارمي : للإمام عبد الله الدارمي ، طا الها

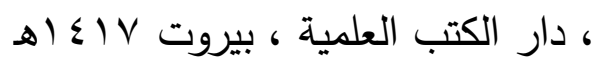

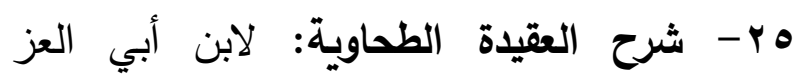

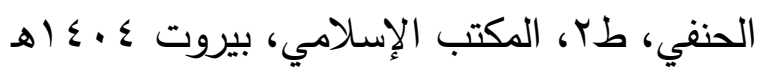

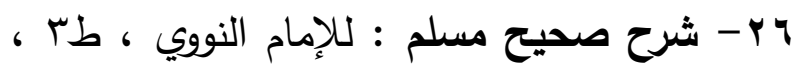

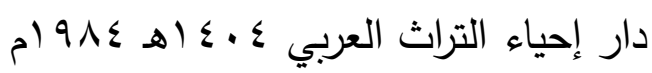

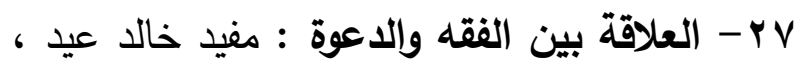

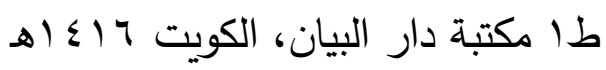

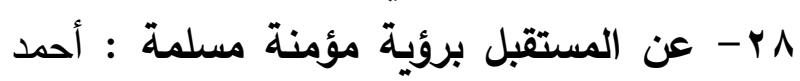

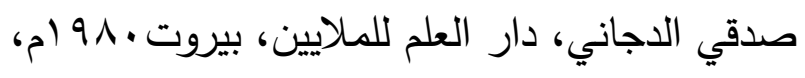
q ج - عون المعبود شرح سنن أبي داوود : للعظيم

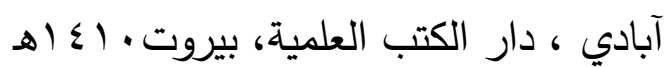

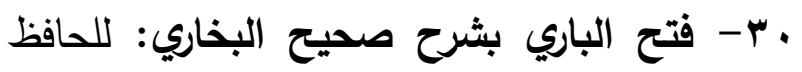

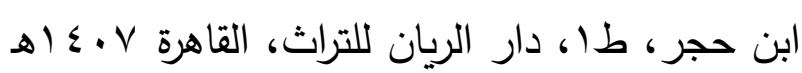
م) اب- فقه الأولويات الدعوية دراسة تأصيلية نحليلية ، لعلي الطالب الشنقيطي ( دراسة دكتوراه للباحث غير منشورة ) لعيل

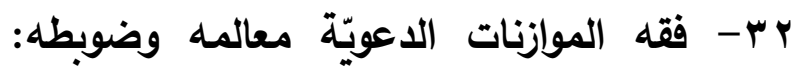

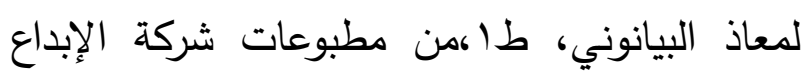

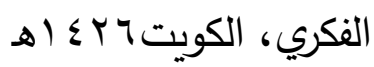

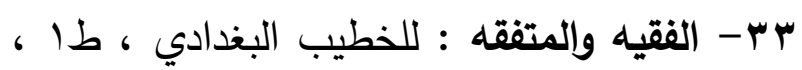

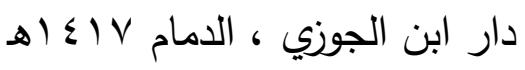

• 1 - تفسير القرآن العظيم : للإمام ابن كثير ، طب . داه

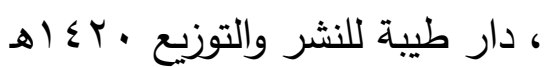
11- التفسير الكبير المسمى ( مفاتيح الغيب ) :

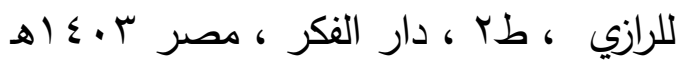

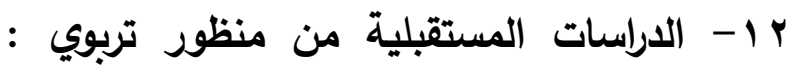

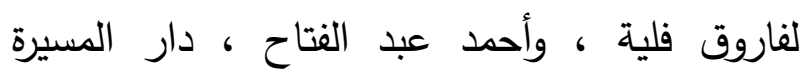

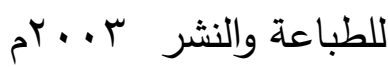

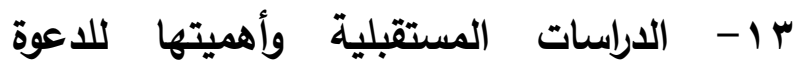
الإسلامية : لعبد الله محمد المديفر ( بحث ماجستير

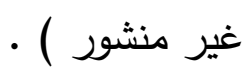
؛ ا- - الدعوة الإسلامية أصولها ووسائلها: لأحمد ؛

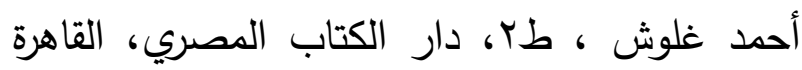
م) $91 \mathrm{D}$ ه \&.V ه - الدعوة إلى الله وأخلاق الدعاة : للشيخ ابن

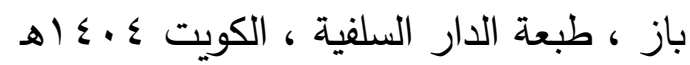

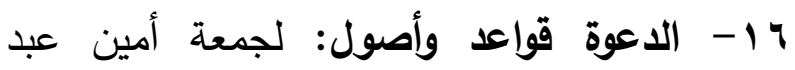

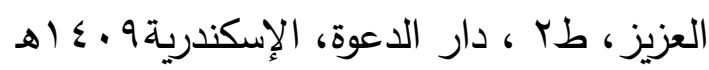

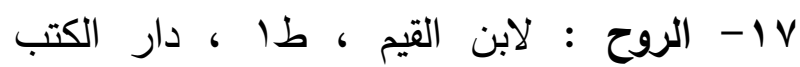

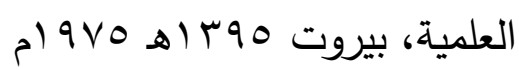
11 - زاد الداعية إلى الله : لمحمد العثيمين، إعداد

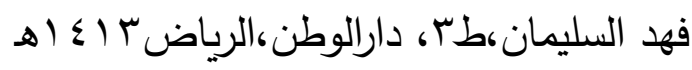
9 ا 19

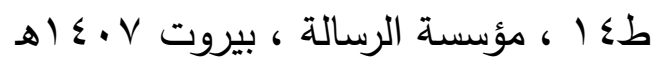

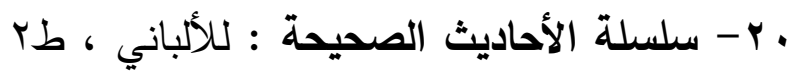

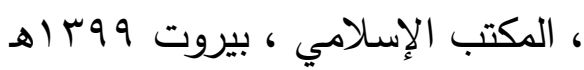

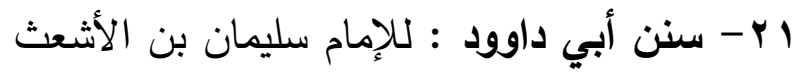

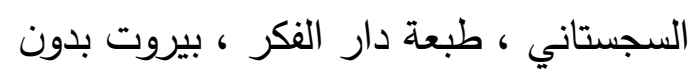


إئ - المعجم الوسيط : مجمع اللغة العربية ، دار

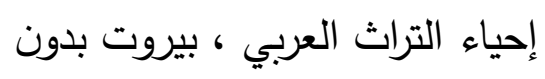

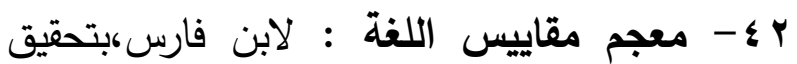

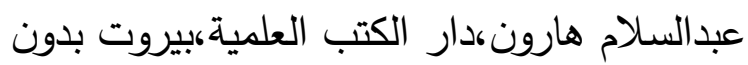

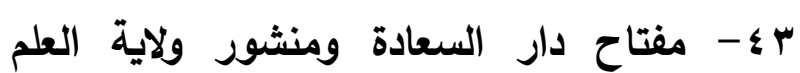

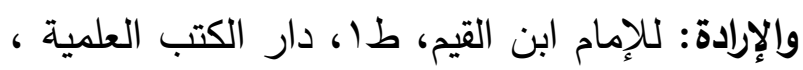

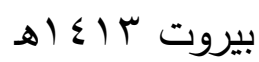
؟ ؛ - المفردات في غريب القرآن : للأصفهاني، تحقيق: محمد كيلاني ، دار المعرفة ، بيروت بدون

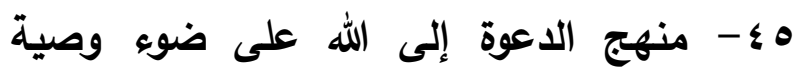

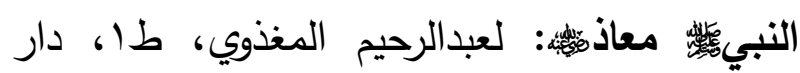

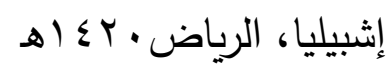

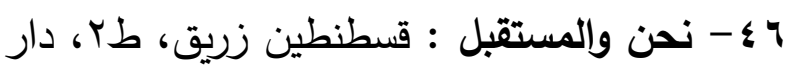

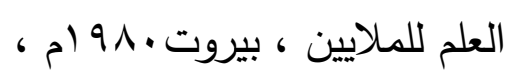

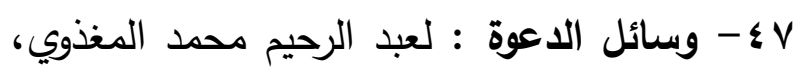

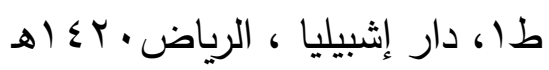

؟ ب- قواعد الدعوة إلى الله : لهمام عبد الرحيم

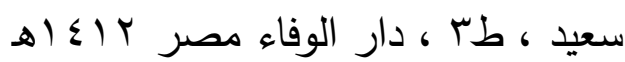

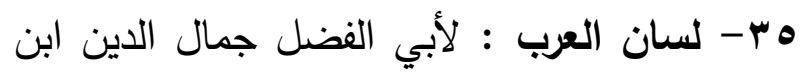
منظور ، دار صادر ، بيروت بدون

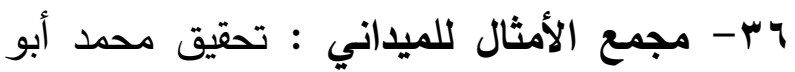

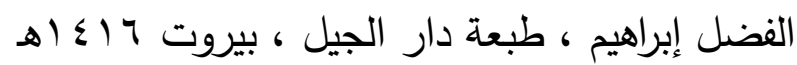

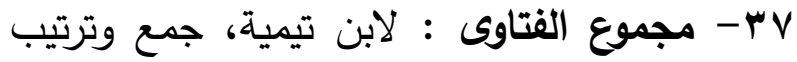

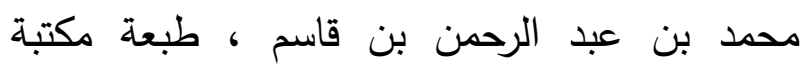
المعارف، الرباط بدون ^r- مدارج السالكين بين منازل إياك نعبد وإياك نستعين : لابن القيم ، طا ، دار الكتب العلمية ، بيروت ب +ع اله : الهن q ب- المدخل إلى علم الدعوة : لمحمد أبو الفتح

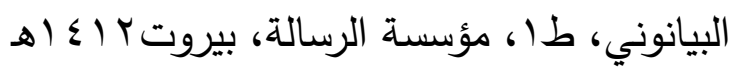

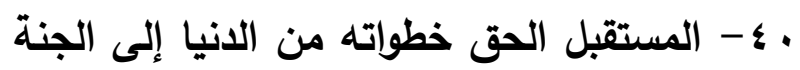

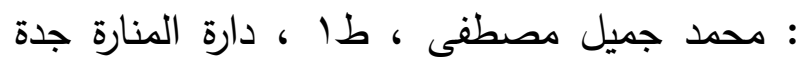
( ) 1819 


\title{
Looking ahead at the future, planning for it and its high necessity for advocacy and advocates: A thorough study in the statement of importance and means of knowledge through the texts of legitimacy.
}

\author{
Ali bin Mohammed Abdullah Al - Amal Al - Shankiti \\ Professor of Advocacy and Islamic Studies, Faculty of Arts and Humanities, \\ Taibah University, Madinah
}

\begin{abstract}
Praise be to Allah, Lord of the Worlds, and prayers and peace be upon the imam of the preachers, who took care of the past, lived the present, looked forward to the future and planned it, and invited the callers and preachers to what they will attempt in the days to come. May Allah bless his dear companions who have done the duty to call to Allah and jurisprudence, delivered the message and performed the secretariat, and said to the people well after.

The vision in the call to Allah, which is the function of the prophets, and the message of Allah in his prudent book that are based on accurate plans of guidance to the righteous path; therefore, the planning of the future is better than falling for its surprises without having any anticipation or appreciation.

The success of the preacher is highly dependent on strength or weakness of the preachers himself in overlooking and planning for the future, which of big importance to the advocacy in depth. Which gives very unacceptable results that lead into failure and confusion. Righteous people need to better look into reasons, plan and trust in Allah, differentiate between desires and potentials, not proceed through imaginations, but from realities.

The subject related to future and looking ahead is connected to all human beings, the life they live and the hours and days they spend. The lessons that connect to human happiness is ultimately responsible for that; because it is the end is what really matters. The absence of planning in the lives of people in general and preachers in particular leads to a lot of confusion and randomness in positions and appreciation of procedures, it also may make ones live in a spiral and confusion due to the lack of clarity of vision, uncertainty starts to control future and ambitions. And because of the misconceptions in some of the concepts of legitimacy, some people become idle and stop thinking beyond their feet.

The future and planning for it has become a necessity in today's world as the world does not get its strength from any artificial muscles or the strength it possesses; but it draws its strength primarily from the power of anticipating the future, planning for it, looking at it and evoking the viewpoint of things. All these ideas must be allotted in the call to Allah in an age that is based on science, and no longer accepts improvisation and demagogy in a matter of life, any serious work of study must be looked at with determination, must be persuasive and feasible before the start and must be planned before implementation. Planning for the future in jurisprudence is an important milestone in the success of the delivery and the success of preachers; because some of sincere preachers were affected by the reality of Muslims bitterness, and the weakness they are in and this directed their results to confuse their work and their words, became floundering in their methodologies, methods and means, starting from the desire to fulfill their duties and ignoring their potentials and abilities.

The great need to look at the future, its anticipation and planning in the life of advocacy and advocacy is solid as advocacy work must have a full vision of the future that is integrated and fully clear being away from improvisation, randomness, confusion, and personal reactions that are prominent in the work of advocacy and reform projects. This would result in stability, which is at the heart of the preparation being ordered by the jurisprudence, which is fully encouraged with all force.

Advocates should be the first to anticipate the future and plan for it, because the advocates' duty is not to let things take place on their own without the use of yesterday's experiences, to monitor the facts of today, to evaluating the right and wrong in the possible interpretations, and to estimate the amount of gains and losses in the period between yesterday and today. A precise knowledge of our energies and potentials material and moral, visible or latent, exploited or wasted, and what are the sources of strength and weaknesses should be estimated and anticipated with all the other considerations and reflections.

The prospect of the future and aspiration should not be taken as a matter of formality, it is the essence of jurisprudence and insight in religion. In addition to dealing with emergencies and hostels, but must exceed research and studies time and space; to open the future prospects for advocacy and advocacy. So as to draw steps and set the road map to call for the parameters studied, jurisprudence, authenticity and contemporary claim. Attention to the future must be present always in the mind of the advocates and must be visible in their scientific and practical efforts; because it is a logical result of the past and present.

We will be keen in this papers to form the root of this fact, clarify some of its features, and identify the most important means in the knowledge of the future, after introducing these methods in a chapter that would improve the importance of looking forward to the future in the life of advocacy and advocates. The subject of looking ahead and
\end{abstract}


planning for it is a wide topic and its relationship with advocacy and advocates increase its capacity and enriches its importance.

The focus of this study is to link the importance of planning and looking ahead with the need for advocacy and advocates in the modern era, which has become to be based on future studies and out looking for the future.

This study at its heart is on the legitimate means of exploring the future, identifying and clarifying future with all reflecting on the holy texts, through the hadiths and the guidance of the Prophet for the advocates; to be a thorough study in the statement of importance and means of knowledge through the texts of legitimacy. 